\title{
Structural evolution of the El Salvador Fault Zone: an evolving fault system within a volcanic arc
}

\author{
C. Canora ${ }^{1}$, J.J. Martínez-Díaz ${ }^{2,3}$, P. Villamor ${ }^{4}$, A. Staller ${ }^{5}$, K. Berryman4, J.A. Álvarez-Gómez² \\ R. Capote ${ }^{2}$ M. Díaz \\ ${ }^{1}$ Departamento de Sismología, Instituto Superior Técnico, Av. Rovisco Pais 1, 1049-001 Lisboa, Portugal. \\ ${ }^{2}$ Departamento de Geodinámica, Universidad Complutense de Madrid, 28040 Madrid, Spain. \\ ${ }^{3}$ Instituto de Geociencias (UCM, CSIC), 28040 Madrid, Spain. \\ ${ }^{4}$ GNS Science, P.O. Box 30-368, Lower Hutt, New Zealand. \\ ${ }^{5}$ ETSI Topografia, Geodesia y Cartografia, Universidad Politécnica de Madrid, Campus Sur, 28031 Madrid, Spain. \\ ${ }^{6}$ Observatorio Ambiental, MARN, Colonia Las Mercedes, San Salvador, El Salvador.
}

e-mail addresses: ccanora@geo.ucm.es (C.C., corresponding author); jmdiaz@ucm.es (J.J.M-D); p.villamor@gns.cri.nz (P.V); a.staller@upm.es(A.S); k.berryman@gns.cri.nz (K.B); jaalvare@ucm.es (J.A.A-G); capote@geo.ucm.es (R.C); MDiaz@marn.gob.sv (M.D)

Received: 28 November 2013 / Accepted: 20 July 2014 / Available online: 30 October 2014

\begin{abstract}
The El Salvador Fault Zone, firstly identified after the 13th February $2001 \mathrm{Mw} 6.6$ El Salvador earthquake, is a $150 \mathrm{~km}$ long, $20 \mathrm{~km}$ wide right-lateral strike-slip fault system. Ruptures along the ESFZ are thought to be responsible for most of the historical destructive earthquakes along the El Salvador Volcanic Arc, as well as for most of the current seismicity of the area. In this work, we focus on the geological setting of the fault zone by describing its geomorphology and structure, using field-based observations, digital terrain modelling, and aerial photograph interpretation with the aim at contributing to the understanding of the ESFZ slip behaviour. In particular, we address the ESFZ structure, kinematics and evolution with time.

The ESFZ is a complex set of traces divided in major rupture segments characterized by different geometry, kinematics and geomorphic expressions. Natural fault exposures and paleoseismic trenches excavated along the fault show that the strike-slip deformation is distributed in several planes. Both geometry and kinematics of the fault zone are consistent with a transtensional strain regime.

The estimated geological slip rate for the main fault segments by paleoseismic trenches and displaced geomorphic features implies a deficit in velocity of the fault compared to the available GPS velocities data. The high vertical scarps of some fault segments would require Quaternary slip rates not coherent neither with measured GPS velocities nor with slip rates obtained from paleoseismic analysis. This mismatch suggests a pre-existing graben structure that would be inherited from the previous regional roll back related extensional stage. We consider that the ESFZ is using this relict structure to grow up along it. As a result, we propose a model for ESFZ development consistent with all these observations.
\end{abstract}

Keywords: El Salvador Fault Zone, active strike-slip fault, 13 February 2001 earthquake, geomorphology, Volcanic arc

Resumen

La Zona de Falla de El Salvador (ZFES) es un sistema de falla de desgarre dextral de $150 \mathrm{~km}$ de longitud y 20 de anchura, que fue identificada por primera vez después del terremoto de Mw 6.6 de El Salvador de febrero de 2001. La mayoría de la sismicidad y de los terremotos históricos destructivos producidos en el arco volcánico salvadoreño han sido producidos por la ruptura de la ZFES. Este trabajo se centra en el marco geológico de la zona de falla describiendo su geomorfología y su estructura a través de observaciones de campo, del estudio de los modelos digitales del terreno y de la interpretación de las fotografías aéreas, con el objetivo de avanzar en el conocimiento del comportamiento de la ZFES. En concreto trataremos del estudio de la estructura, la cinemática y la evolución de la ZFES.

La ZFES es un complejo sistema de fallas divididas en varios segmentos que se diferencian en la geometría, la cinemática y la expresión geomorfológica. En los afloramientos de la falla, así como en las trincheras paleosismicas excavadas se ha observado que la deformación de desgarre está distribuida en varios planos y tanto la geometría como la cinemática de la zona de falla indican que la ZFES está bajo un régimen de deformación transtensional. 
La tasa de deformación estimada para los principales segmentos a través del estudio paleosísmico y del análisis de indicadores geomorfológicos desplazados nos muestra un déficit de velocidad para la falla si lo comparamos con los datos obtenidos por GPS. Estos datos tampoco ayudan a explicar la existencia de grandes escarpes verticales que se observan en algunos segmentos de la falla, y que requerirían tasas de deformación muy elevadas. Esta discrepancia sugiere la existencia de una estructura de graben preexistente que puedo ser producida por el "roll-back" de la placa y que creó una fase extensional en el arco volcánico. En este trabajo consideramos que la ZFES está actualmente desarrollándose sobre la estructura extensional relicta y como resultado proponemos un modelo estructural consistente con estas observaciones.

Palabras clave: Zona de Falla de El Salvador, falla activa de desgarre, terremoto 13 Febrero 2001, geomorfología, Arco Volcánico

\section{Introduction}

Large strike-slip faults are important structural features that may accumulate displacements for tens or hundreds of kilometres being capable of generating very large, devastating earthquakes. The El Salvador Fault Zone (ESFZ) is one of these features, extending along the El Salvador volcanic arc (Fig 1) for about $150 \mathrm{~km}$ long as a right-lateral strike-slip fault system, as wide as $20 \mathrm{~km}$ (Martínez-Díaz et al., 2004). The ESFZ was firstly identified after the $13^{\text {th }}$ February 2001 Mw $6.6 \mathrm{El}$ Salvador earthquake that ruptures the $21 \mathrm{~km}$ long San Vicente segment (Canora et al., 2010). Ruptures along the ESFZ are responsible for most of the historical destructive earthquakes along the El Salvador Volcanic Arc, as well as for of the current small to medium size earthquakes occurring in the area (Canora et al., 2010).

To date, studies on the ESFZ have mainly addressed aspects of fault structure at a local scale (Corti et al., 2005), tectonic modelling of the area (Álvarez-Gómez et al., 2008) and current GPS velocities (DeMets, 2001 and Correa-Mora et al., 2009). In this study, we analyse in detail the ESFZ geomorphology and structure by using field-based observations and digital terrain model (DTM), aerial photographs and Quickbird images interpretation. The scope is to assess the ESFZ slip behaviour during individual earthquakes by better defining both its structure and kinematics resulting from cumulative slip events. Moreover, we investigate if the known fault zone is accounting for all the deformation in the region or if, on the contrary, there might be other active tectonic structures in the area. We finally examine the significance of our results for the overall development of the El Salvador Volcanic Arc and the role of the ESFZ in the accommodation of the regional tectonic strain. The results of this work are important to characterize the seismic sources and better define the seismic hazard of El Salvador.

\section{Geological and seismotectonic setting}

The ESFZ is located along the northern sector of the Central American Volcanic Arc. The arc runs parallel to the Middle America trench from Guatemala to Costa Rica and is associated with the subduction of the Cocos plate under the Caribbean plate. The arc ends abruptly in the north against the Polochic fault in Guatemala (Fig. 1), which forms the western tip of the Motagua - Polochic - Swan Island transform system on the boundary between the Caribbean and North American plates. The interaction of the North American, Caribbean and Cocos plates forms a diffuse triple junction, distributing the tectonic strain over a wide area (Guzmán-Speziale et al., 1989; Guzmán-Speziale and Meneses-Rocha, 2000; Lyon-Caen et al., 2006; Plafker, 1976).

The Cocos plate converges slightly obliquely towards the Caribbean plate with a relative velocity of $70-85 \mathrm{~mm} / \mathrm{yr}$ (DeMets, 2001). The strike-slip movement along the ESFZ has been used to propose different kinematic models. For example, DeMets (2001) considers the NW displacement of the forearc sliver between the Mesoamerican Trough and the Central American volcanic arc as the result of strain partitioning along the margin. Margin parallel movement is accommodated by strike-slip regime along the volcanic arc (Fig.1). Numerical and geodynamic models considering relative movements of kinematic blocks around the Chortis Block (bounded by the ESFZ to the SW) suggest that, most likely, the strike-slip regime along the volcanic arc is driven by the eastward drift of the Caribbean plate (Álvarez-Gómez et al., 2008). This latter model is supported by recent GPS measurements at 21 sites in El Salvador and southern Honduras. All stations in the forearc move $14 \pm 2 \mathrm{~mm} / \mathrm{yr}$ to the west-northwest, parallel to the trench without any vertical displacement, consistent with weak or no coupling of the subduction interface (Correa-Mora et al., 2009), suggesting that stress partitioning does not occur.

El Salvador region shows a very high seismic activity associated with two active tectonic systems: (1) the Middle America Trench subduction zone, generating large magnitude earthquakes ( $\mathrm{Mw}>7)$; (2) the upper crustal volcanic arc deformation zone, generating moderate to large magnitude earthquakes $(\mathrm{Mw} \leq 7)$. Subduction interface ruptures at shallow-intermediate depths $(<200 \mathrm{~km})$ tend to cause moderately intense shaking across large parts of southern El Salvador. The largest earthquakes in the area (1921, 1932, 1982 and 2001 A.D.) occurred in the subduction zone, and were characterized by almost identical normal-slip mechanisms with slip planes oriented $\mathrm{N} 120^{\circ}-130^{\circ} \mathrm{E}$. The most recent example of such an event is the Mw 7.7 earthquake of 13 January 2001, which produced MMI VII at San Salvador city (Bommer et al., 2002). 
Fig. 1.- Tectonic setting of northern Central America. a) Tectonic plates, major crustal blocks and faults. Arrows show relative displacements with fixed Caribbean plate (DeMets, 2001). Abbreviations are: PF, Polochic fault; MF, Motagua fault; SIT, Swan Island transform; SG, Sula graben; IG, Ipala graben; HD, Honduras depression; GF, Guayape fault; ND, Nicaraguan depression; HE, Hess escarpment. b) RADAR SRTM image of El Salvador with historically destructive earthquakes (white circles) and instrumental epicenters (Ms $>2.5$, period 1977-2001) from USGSNEIC catalogue (small dots). Smaller focal mechanism symbols are for events of $\mathrm{Mw}$ $>5.5$ (1977-2001, Harvard CMT database) and large focal mechanism symbols are for events of $\mathrm{Mw}>6.5$ (from Bufforn et al., 2001). ESFZ: El Salvador fault zone. White dashed line shows the El Salvador border.
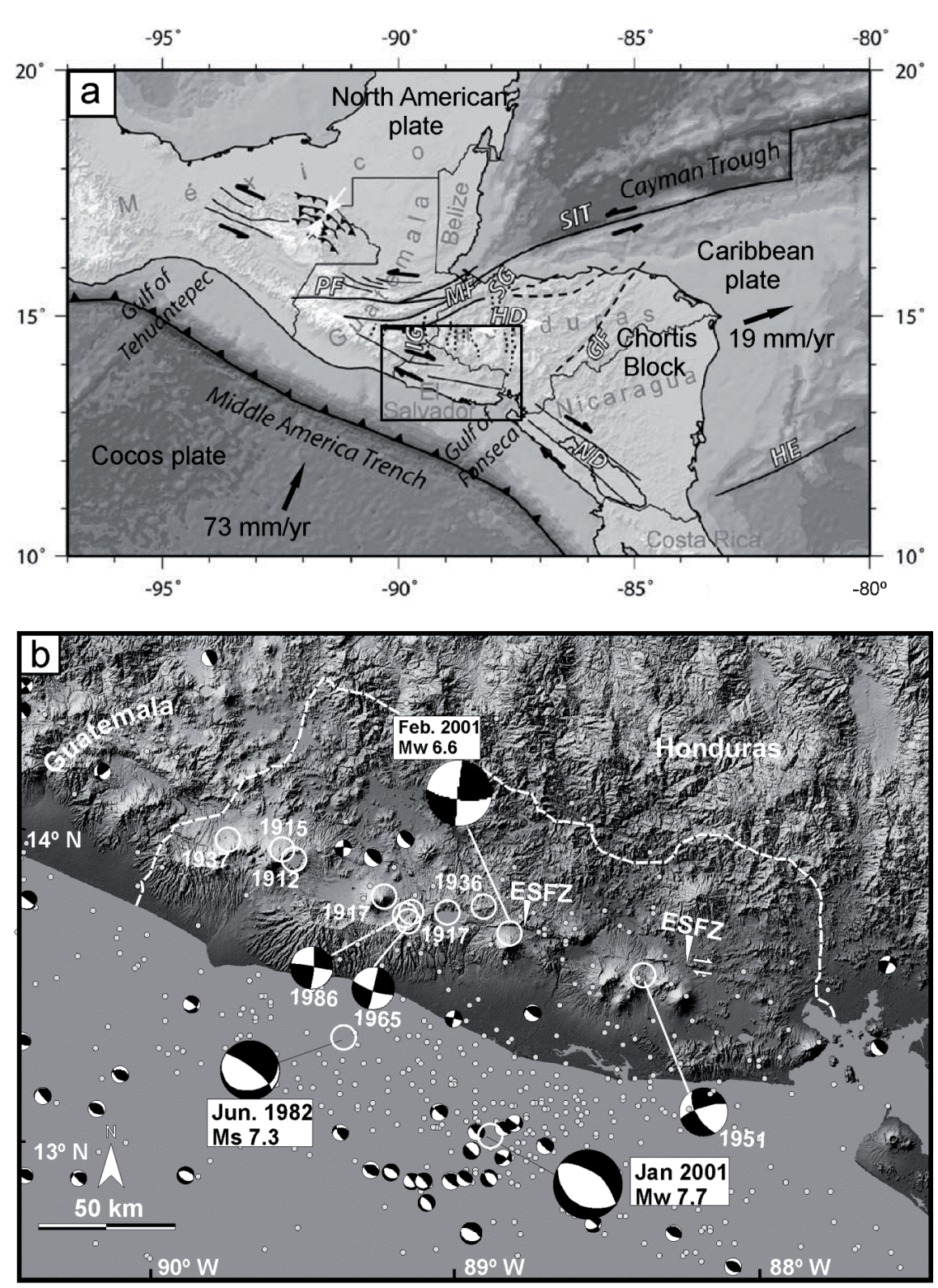

The shallow crustal earthquakes (depths $<20 \mathrm{~km}$ ) along the Quaternary volcanic chain (e.g., Dewey et al., 2004), accommodate trench-parallel strike-slip motion (White et al., 1987) and have been considered limited to smaller magnitudes (Mw 5.5-6.8). The 11 destructive shallow crustal earthquakes that took place in the twentieth century are significantly aligned along the volcanic arc (Fig.1b). On 8 June 1917, a Ms 6.4 earthquake occurred 30-40 km west of the San Salvador volcano, followed by a Ms 6.3 earthquake. On 28 April 1919, San Salvador was again damaged, this time by a shallow earthquake of Ms 5.9, the epicentre of which was situated at about the same location of a later earthquake that took place in 1986 (Mw 5.7). The latter event originated on the volcanic arc and propagated along a nearly vertical, north-northeast-striking plane (White et al.,
1987). Four reliable focal mechanisms are available for the more recent major events of 1951, 1965, 1986, and February 2001 (Martínez-Díaz et al., 2004). They are all strike-slip events, with one of the nodal planes oriented nearly eastwest, parallel to the volcanic arc. The Mw 6.6 event of 13 February 2001 is the most recent example of a volcanic arc earthquake of this type (Bommer et al., 2002). Recent paleoseismic studies suggest that the ESFZ may be capable of generating large magnitude earthquakes ( $\mathrm{Mw}>7.0)$ (Canora et al., 2012). Due to their shorter recurrence intervals, shallow depths, and close proximity to population centres, upper crustal earthquakes within the volcanic arc have produced far greater destruction in El Salvador than the less frequent, very large-magnitude earthquakes that originated in the subduction zone (White and Harlow, 1993). 


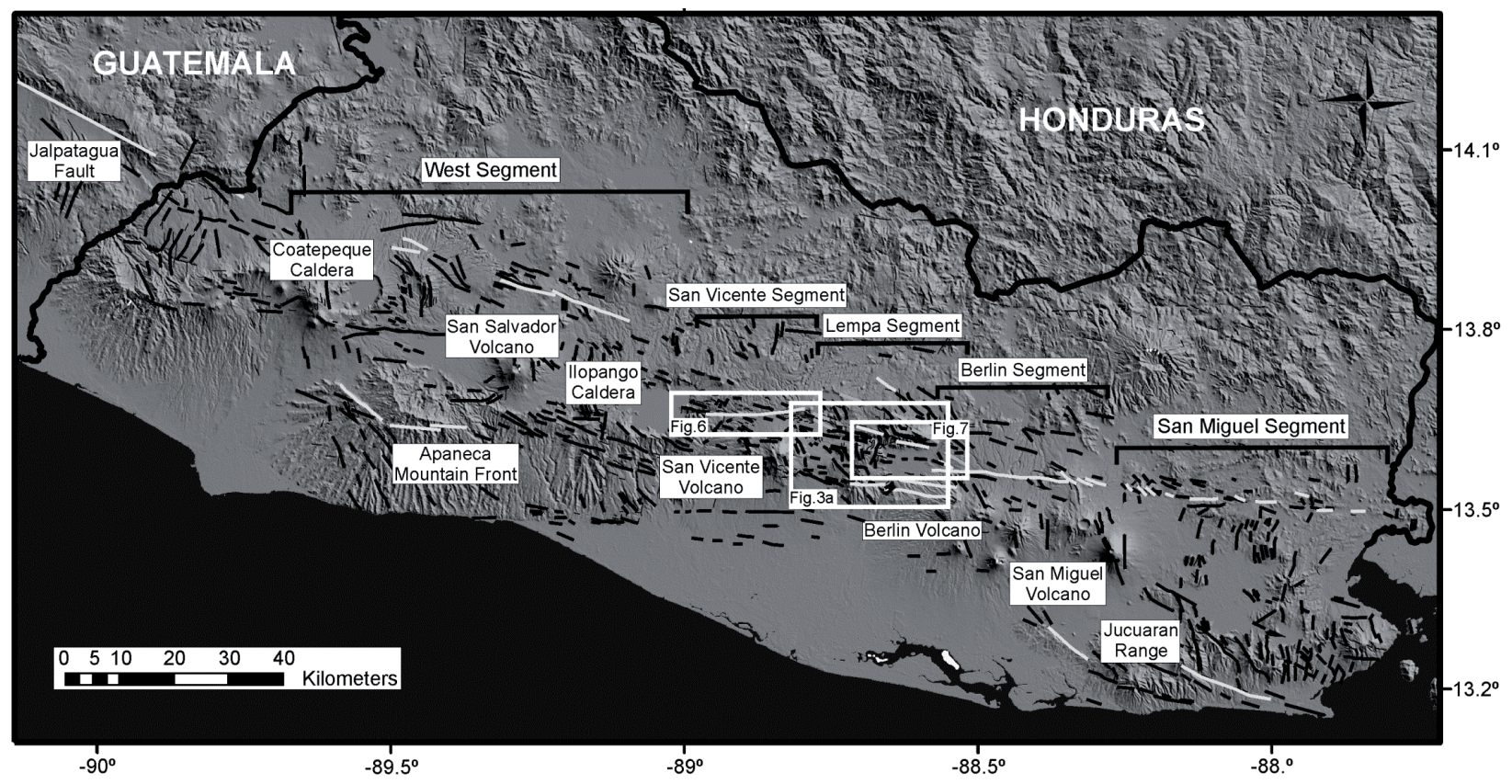

Fig. 2.- Active fault traces and fault segments of the El Salvador Fault Zone over a ten- metre resolution Digital Terrain Model (DTM) derived from 1:25.000 topographic map. Light grey traces are the active faults with larger displacements. Areas enclosed in rectangles correspond to Figs. 3a, 6 and 7.

\section{Structure and kinematics of the El Salvador Fault Zone}

To date, only a few studies have analysed the tectonic structure of the El Salvador Fault Zone (ESFZ) (Fig. 2). In the following sections, an active fault map derived from the analysis of geomorphic expression of deformation features, resulting from cumulative long term fault movements (Section 3.1) is presented. Then, both structural and kinematics aspects identified in the field are reported (Section 3.2) and the fault slip rates are estimated (Section 3.3). Finally, a GPS data analysis is performed (Section 3.4) and the average fault slip rate is estimated from displaced geomorphic features and compared them with GPS velocities data (Section 3.5).

\subsection{Fault trace geometry}

We have produced a map of Late Quaternary fault traces using aerial photos, a 10 meters resolution Digital Terrain Model (DTM) derived from topographic maps at 1:25000 scale, and field observations (Fig.2). Active fault traces are identified by showing clear surface offsets affecting Quaternary materials and/or the drainage system (Fig.1 repository data).

The ESFZ appears as a complex network of traces (Fig.2), and it is divided in various major rupture segments based upon their different geometry, kinematics and geomorphic expression (Canora et al., 2010). The segmentation is based on detailed field observations conducted along the fault zone, from the Ilopango Caldera to the Berlin volcano area $(\sim 70$ $\mathrm{km}$, Fig.2), and is coherent with the seismic series of February 2001 in terms of location, rupture limits and magnitude.
Figure 2 shows, from west to east, the five distinguished segments. In the western segment, the fault zone is represented by numerous $\mathrm{N} 120^{\circ} \mathrm{E}$ trending strands within a $20-40 \mathrm{~km}-$ wide zone that merges towards the west into the Jalpatagua Fault in Guatemala. This segment is a $40 \mathrm{~km}$ wide and $80 \mathrm{~km}$ long fault zone and shows a graben-like structure, with the active volcanoes located along the middle graben axis. In the middle of this area, the active calderas and volcanoes occupy the low topographic zones forming an elongated, NW-SE trending basin bounded by NW-SE strike-slip faults with minor normal component. The faults bounding this depression to the north have south-facing scarps, while the southeastern faults have north-facing scarps (the Apaneca mountain front). In this structure we can also identify many NNW-SSE and NNE-SSW faults, which could be associated with the presence of the volcanoes. E-W and ENE trending pure strike-slip faults cut through the Apaneca range and the depression.

The San Vicente, Lempa and Berlin segments (Fig.2) are characterised by right-laterally stepped fault traces that form a transtensional region. In this area, the fault can be easily identified because the main fault traces have more continuity. Those segments are a $20 \mathrm{~km}$ wide and $80 \mathrm{~km}$ long fault zone comprising three different sets of faults: (1) NNW trending normal faults with minor horizontal component; (2) NW trending strike-slip faults with minor normal component; (3) W-E trending pure strike-slip faults.

Right-lateral stepping of the main fault trace from the Berlin area to the San Vicente area produces a pull-part structure (Fig.3). Close to the Lempa River (Fig.3a), the right lateral stepping of these strike-slip faults favours a local extensional regime opening a narrow pull-apart basin (Lempa basin). The 
Lempa basin infill does not display significant geomorphic fault scarps due to high sedimentation rates.

In figure 3, the Lempa basin fault network is compared with a trantensional pull-apart analogue model proposed by Wu et al. (2009). A good correlation is shown in terms of fault distribution and kinematics. Thus, the geomorphology and surface structures of the ESFZ in this area show the rightlateral movement of the fault as well as the transtensional component inside the pull-apart structure.

The San Miguel segment is a $60 \mathrm{~km}$ long area made up of several small, left stepping, en-echelon NW trending faults and small W-E fault traces that point out a principal $\mathrm{E}-\mathrm{W}$ displacement zone. In this segment no important vertical displacements are documented, and there is no significant change in elevation of the mountains on either side of the fault. The aforementioned evidences are consistent with a pure strike-slip kinematics of the fault.

The strike-slip deformation in this part of the ESFZ appears to be transferred, to the south, to the Jucuaran Range. In this area, we can distinguish two main fault sets displacing young deposits and landforms: N-S normal faults, and WNW-ESE oblique faults (normal faults with minor strike-slip component). Those structures may indicate an extensional, or transtensional, regime.

Figure 4 shows the active faults of the ESFZ superimposed on the geological map in order to observe differences in the faults surface expression with the age and type of materials. The figure shows a higher number of faults in the oldest materials, however, the length of these traces do not seem to be related with the lithology.

\subsection{Fault structure observations and kinematics at surface}

Fault exposures have been analysed along the ESFZ to assess their kinematics. Data were gathered from metric scale outcrops located along road cuts and within quarries and paleoseismic trenches excavated along the San Vicente segment (Canora et al., 2012).

Data from paleoseismic trenches are consistent with strikeslip deformation being distributed along many slip planes over a width of 10 to $25 \mathrm{~m}$ and characterized by different attitudes (Fig.4). Most of the slip planes probably merge together at depth, resembling a branching upward structure common in strike-slip fault zones (Price and Cosgrove, 1990).

Along the $28 \mathrm{~km}$ of the Lempa segment, strike-slip activity post-dates substantial vertical displacements. In fact, an outcrop of the main fault located nearby the La Leona landslide, in the Panamerican Highway (Fig.3), the Quaternary volcanic deposits result displaced by normal faults which, in turn, are displaced by younger strike-slip faults (Fig.5).

In other 22 selected sites, structural analysis was carried out on rocks of Miocene to Holocene ages (Figs. 6 and 7).

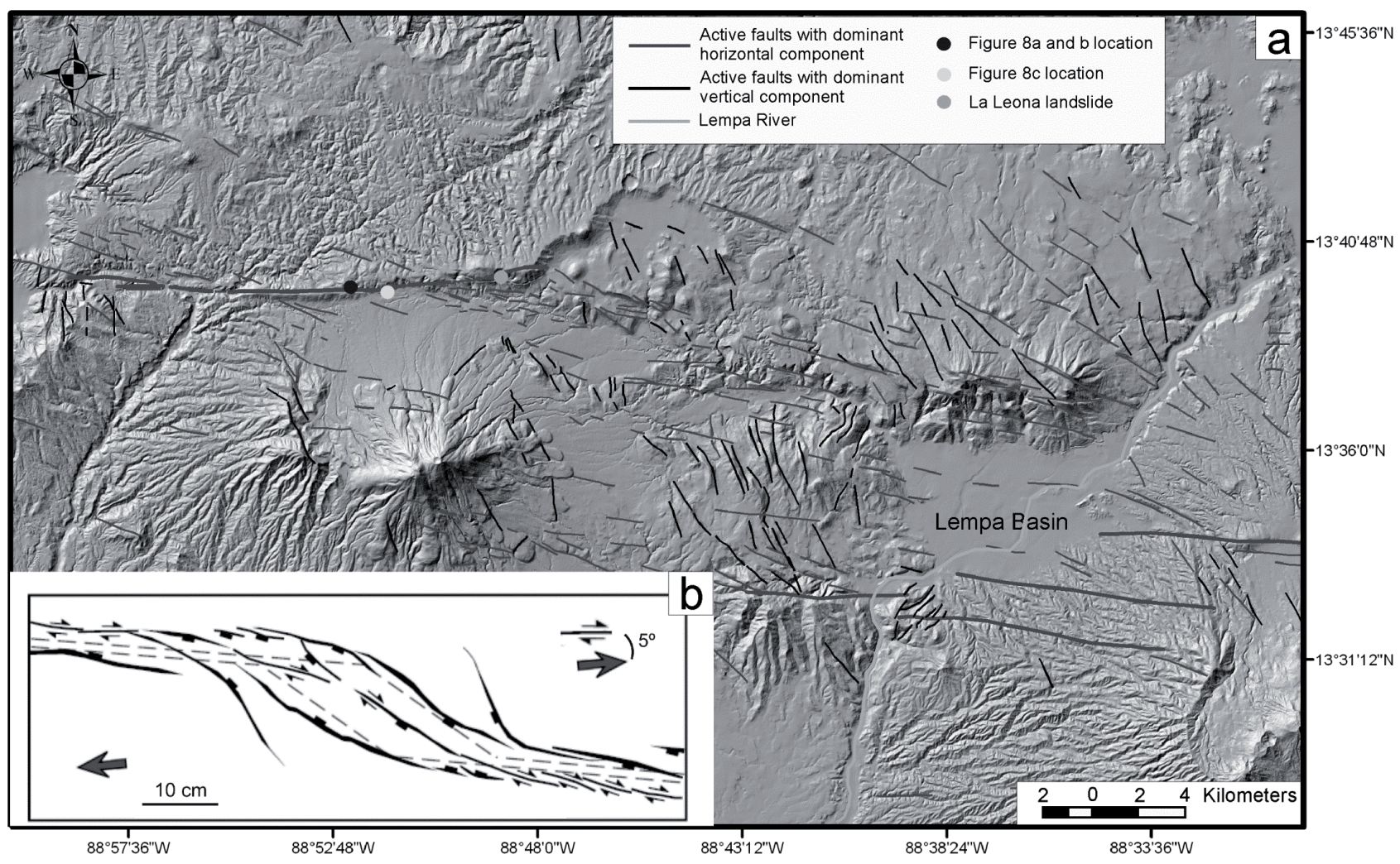

Fig. 3.- a) Active faults of the Lempa pull-apart basin over DTM. Grey lines are the active fault traces with dominant horizontal component and black lines are the active faults with dominant vertical component. b) Transtensional pull-apart model taken from Wu et al. (2009). 


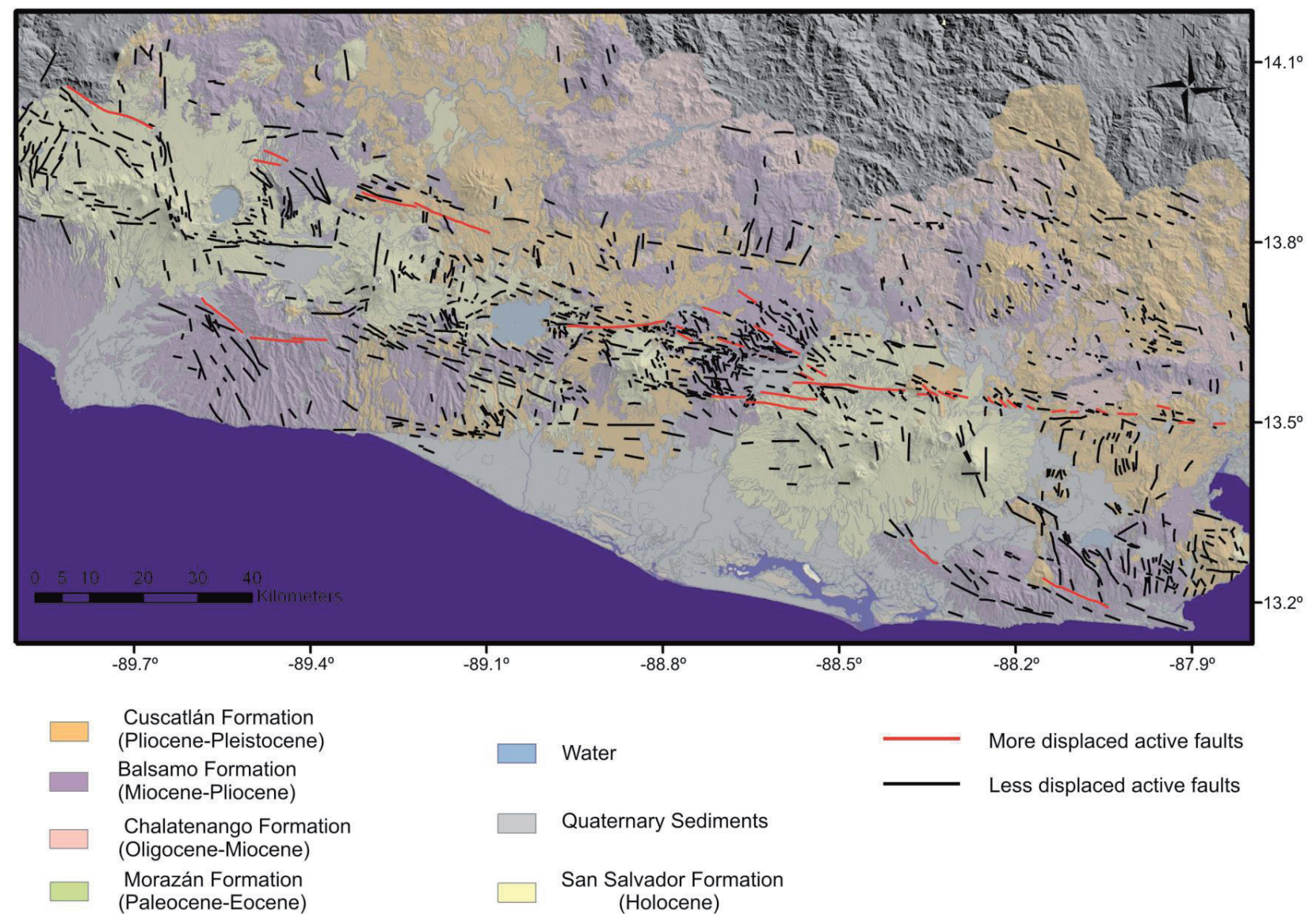

Fig. 4.- Active fault map of ESFZ over the geological map and the DTM.

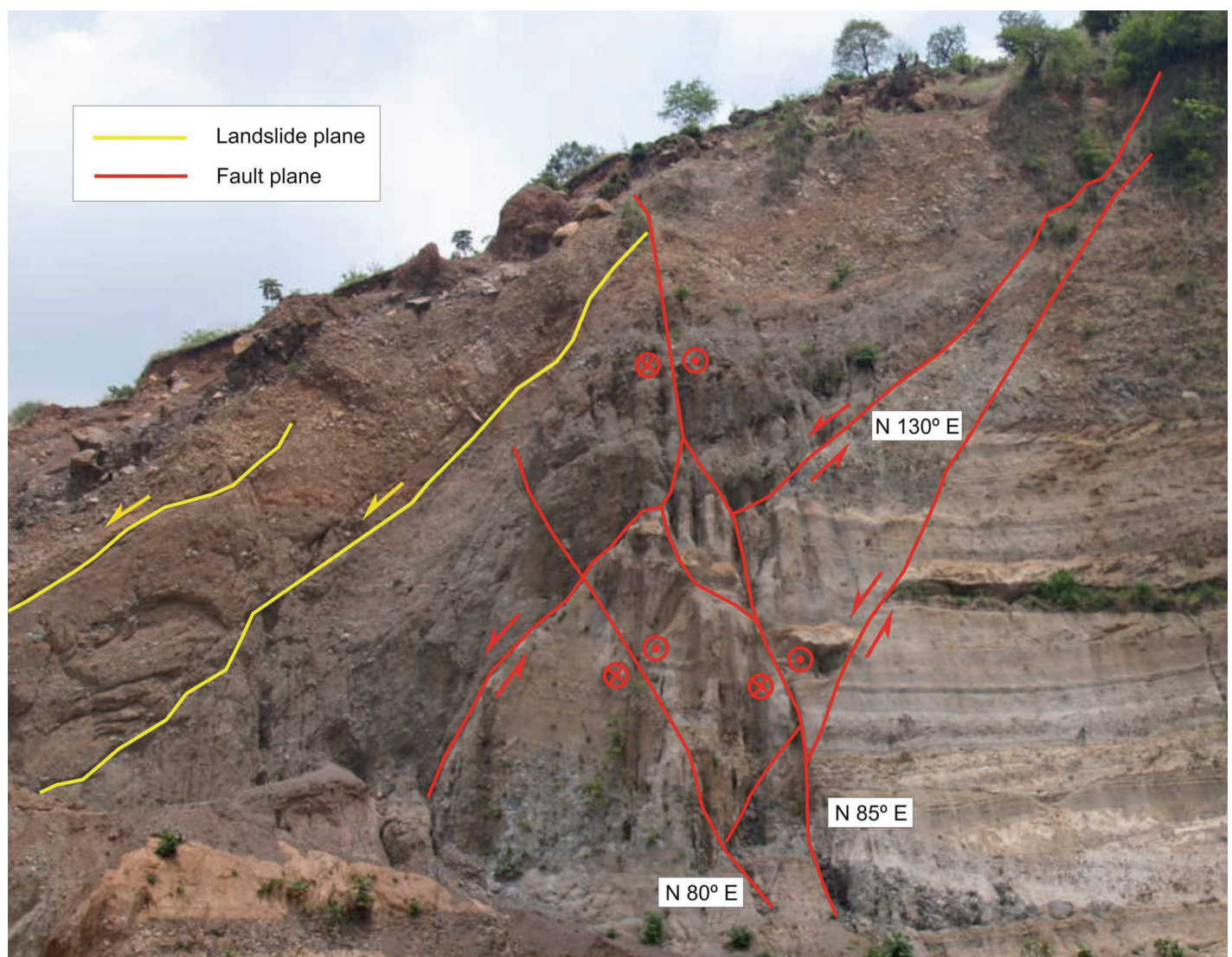

Fig. 5.- Photograph of La Leona site showing crosscut relations between faults. The volcanic deposits are deformed first by normal faults, and then by young strike-slip faults. The volcanic materials are also displaced by surficial landslides. 
Slip plane orientations suggest that most of the faults are secondary to the main E-W strike-slip zone and are coherent with Riedel ( $\mathrm{R}$ and R') and Y planes (following the terminology of Logan et al., 1979, and Tchalenko and Ambraseys, 1970). The structure along the ESFZ resemble the secondary features observed in the experimental studies carried out by Riedel (1929) and Tchalenko (1968), which commonly form in cover sediments above a major strike-slip basement fault. Striations on slip planes show dextral movement with minor normal component supporting a dominant transtensional strain regime, with SHmax and SHmin oriented $\sim \mathrm{N} 160^{\circ} \mathrm{E}$ and $\sim \mathrm{N} 70^{\circ} \mathrm{E}$ respectively.

The most common metric-scale structures present along the main fault zone are en echelon tension cracks, push-up ridges and blocks (e.g. Fig.8a), shutter ridges (e.g. Fig.8b), small fault scarps and highly fractured areas (e.g. Fig.8c). The orientation of these structures is consistent with predominantly right-lateral kinematics. An oblique component of displacement can be revealed by en-echelon fault segments, with a left-stepping pattern usually indicating right-lateral movement. In some localities, the fault ruptures occurred either as single or multiple linear tracks extending for several hundreds of metres parallel to the overall fault trace as those who were observed along the February 2001 El Salvador earthquake rupture (Canora et al., 2012).

\subsection{Slip rate estimates}

Using a digital terrain model, the likely total cumulative displacement across the fault, as well as the ages of geological formation and landscapes surfaces, are used to calculate the fault slip rate. Three fault displacement datasets, which represent shorter to longer time frames are considered; 1) displacements measured from detailed logging of fault exposures in paleoseismic trenches, which represent the accumulated displacement of a few coseismic displacements during the last 10,000 years; 2) offsets of rivers and streams crossing the fault, which provide evidences of accumulated displacements around $40 \pm 5 \mathrm{ka}$ and; 3 ) offsets on large geologic features as volcanic calderas or ridges, which give insights on long term horizontal and vertical displacements $(>1 \mathrm{Ma})$.

Slip rate estimates from paleoseismic trenches were acquired along the San Vicente segment of ESFZ where we have the best geomorphic expression of the fault scarp. Along other segments, the fault scarp is difficult to identify because of the occurrence of a pervasive vegetation cover. Data from paleoseismic trenches (presented on Canora et al., 2012), are consistent with a dextral strike-slip rate with an average value of about $4.1 \pm 0.7 \mathrm{~mm} / \mathrm{yr}$ for the last $5.5 \mathrm{ka}$ (Table 1 ).

River offsets by the fault are difficult to identify along the ESFZ with the available DEMs and remote sensing images

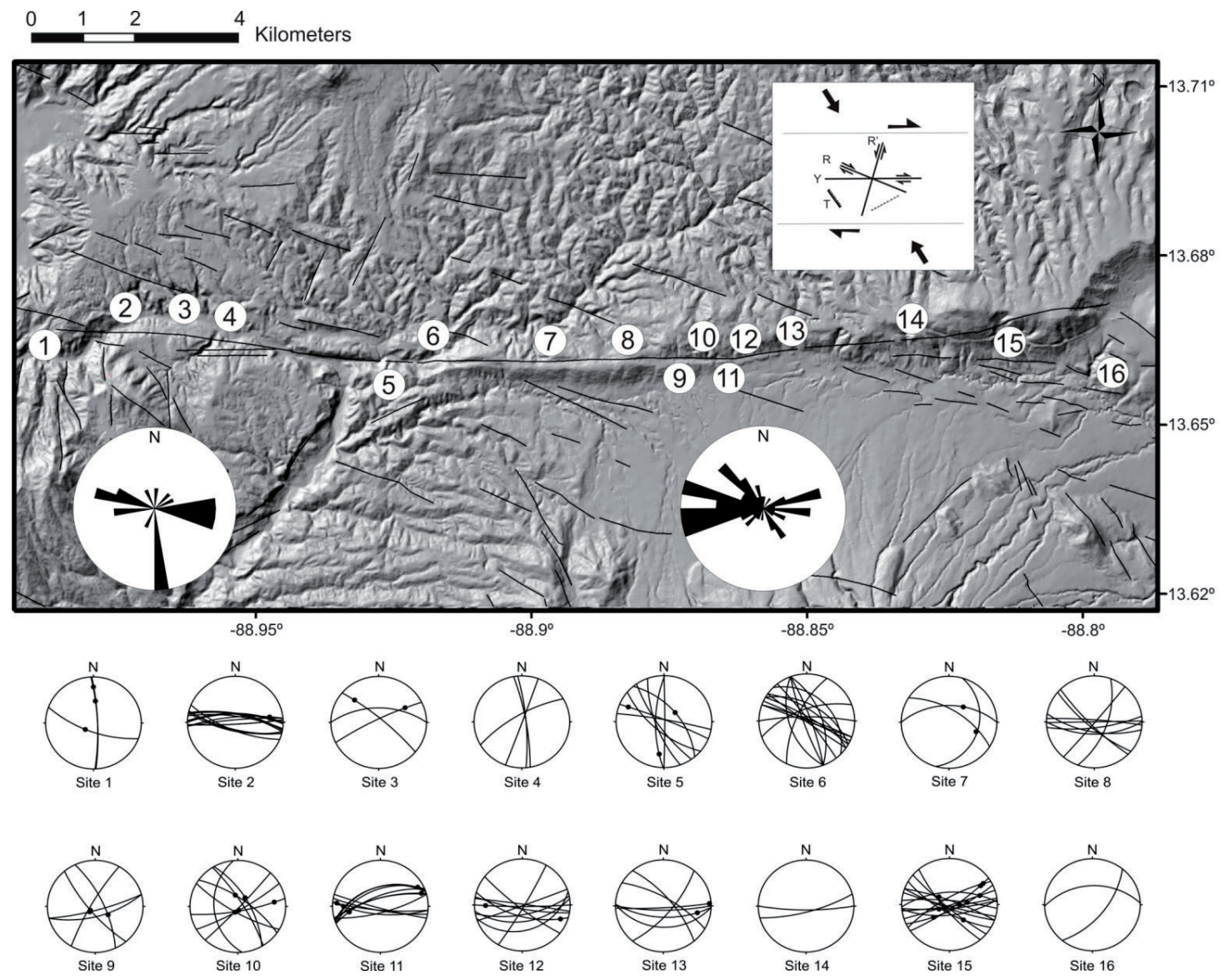

Fig. 6.- Stereographic representation and rose diagrams of the fault data collected along the San Vicente segment of the ESFZ. Numbers indicate location of the fault analysis stations. Base map is the ten-metre resolution DTM. 


\begin{tabular}{ccc}
\hline Source & Time & Slip-rate \\
\hline $\begin{array}{c}\text { Trenches } \\
\text { (Canora } \text { et al., 2012) }\end{array}$ & $5.5 \mathrm{ka}$ & $4.1 \pm 0.7 \mathrm{~mm} / \mathrm{yr}$ \\
$\begin{array}{c}\text { River Offsets (This study) } \\
\text { Triunfo }\end{array}$ & $36 \mathrm{ka}$ & $5.5 \pm 0.5 \mathrm{~mm} / \mathrm{yr}$ \\
Desague & $40 \mathrm{ka}$ & $5 \pm 0.5 \mathrm{~mm} / \mathrm{yr}$ \\
Large Structures Offsets & c. 1 Ma & $3-5.3 \pm 0.5 \mathrm{~mm} / \mathrm{yr}$ \\
$\begin{array}{c}\text { (This study) } \\
\text { GPS velocities }\end{array}$ & $\begin{array}{c}\text { Interseismic } \\
\text { data }\end{array}$ & $10 \mathrm{~mm} / \mathrm{yr}$ \\
\hline
\end{tabular}

Table 1.- Minimum dextral-slip displacement rates $(\mathrm{mm} / \mathrm{yr})$ on the central-east section of El Salvador Fault Zone.

(Quickbird). The clearest offset was described by Corti et

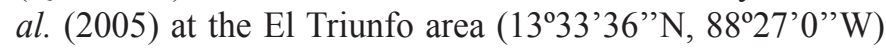
where, according to these authors, a stream shows horizontal displacement of $\sim 400 \mathrm{~m}$. Our measurement of the stream offset with the LaDiCaoz software (Zielke and Arrowsmith, 2012), however, shows a horizontal slip of $\sim 200 \pm 20 \mathrm{~m}$ (Fig.9). According to Corti et al., 2005, the age of the drainage system is younger than $36 \mathrm{ka}$. Using that age, our calculated minimum slip rate along the fault yield values of $5.5 \pm$ $0.5 \mathrm{~mm} / \mathrm{yr}$ (compared to $11 \mathrm{~mm} / \mathrm{yr}$ of Corti et al., 2005).
Another river offset along the ESFZ was described by Canora et al. (2012), at Desague area. The regional landscape and drainage system in this area is repeatedly reset by ignimbrite eruptions from the nearby Ilopango caldera. In particular, the Tierra Blanca 3 eruption and associated ignimbrite body of $40 \mathrm{ka}$ (Rose et al., 1999) filled the landscape and brought it to an almost planar surface, which was subsequently incised by the fluvial system. In the Desague area (Fig.10), the ESFZ is made up of three parallel strands, two of them show a 200 \pm 20 m right-lateral offset (calculated with LaDiCaoz) affecting several fluvial channels. This lateral displacement, and the maximum c. $40 \mathrm{ka}$ age of the drainage system, provides a minimum slip rate of $5 \pm 0.5 \mathrm{~mm} / \mathrm{yr}$.

For long term displacements, we analysed the geometry of large geological formations. We have measured the displacement of two old calderas along the ESFZ, whose ages are defined from the age of the younger deposits related to the caldera collapses. Figure 11a shows La Carbonera Caldera (Rotolo and Castorina, 1998), to the south of the main fault trace, and the possible continuation of the fault zone to the northeast with the presence of a large scarp on MiocenePliocene Balsamo Formation materials. We measure an offset of La Carbonera Caldera (Fig.11a) of $9 \pm 1 \mathrm{~km}$ for the last 1.7 Ma (Rotolo and Castorina, 1998), which lead us a slip

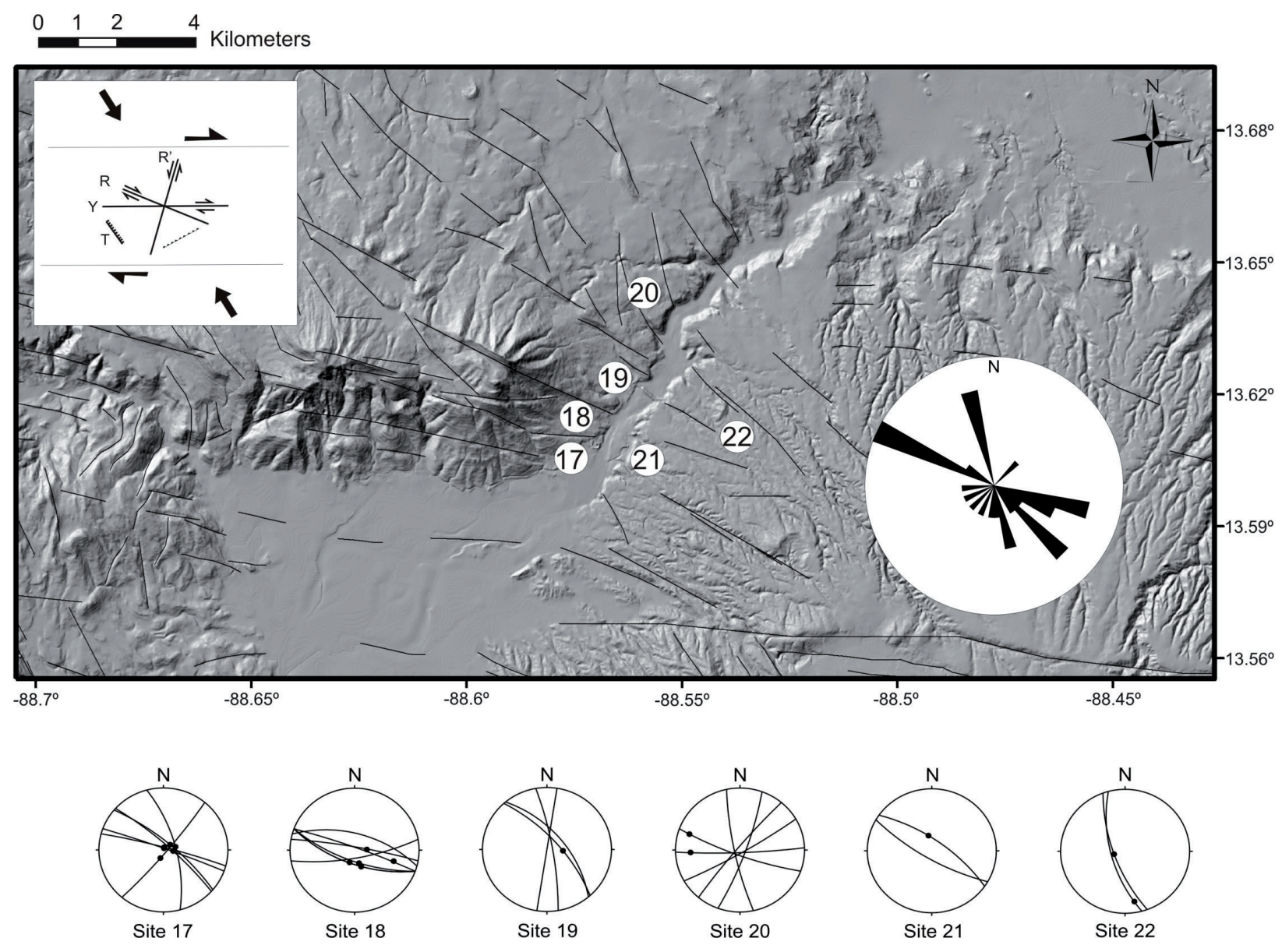

Fig. 7.- Stereographic representation (lower hemisphere) and rose diagram of the fault data collected along the Lempa segment of the ESFZ. Numbers indicate location of the fault analysis stations. Base map is the ten-metre resolution DTM. 

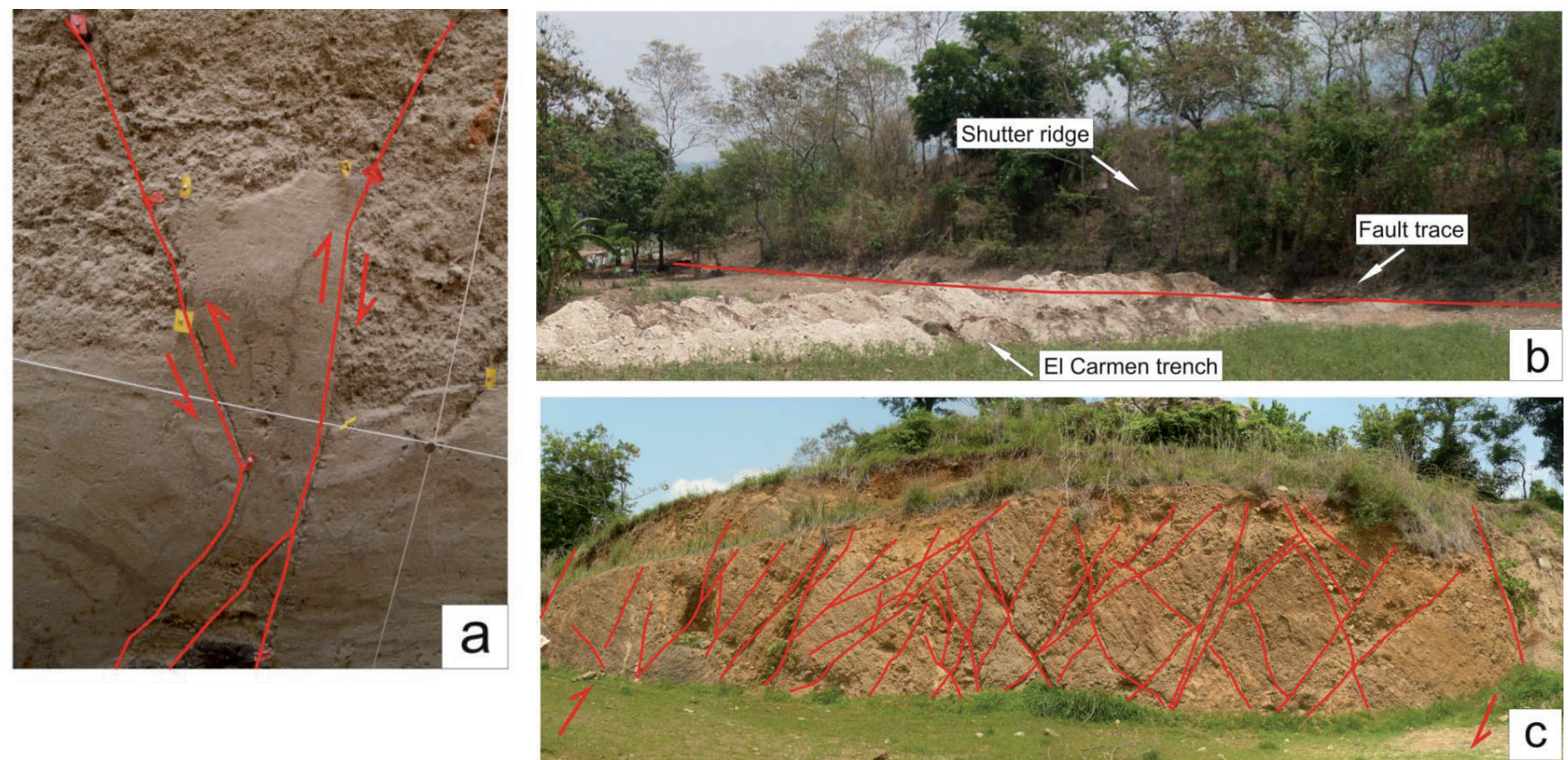

Fig. 8.- Examples of structures related with the movement of ESFL. a) Photograph of a push up structure typical of strike-slip taults in a paleoseismic trench located along the San Vicente segment. b) Shutter ridge produced by the displacement of the fault with time. The fault plane runs at the base of the structure where a paleoseismic trench is located. c) Outcrop along the ESFZ with a high fault complexity and forming a positive relief limited by two main fault planes at the extremes.

a

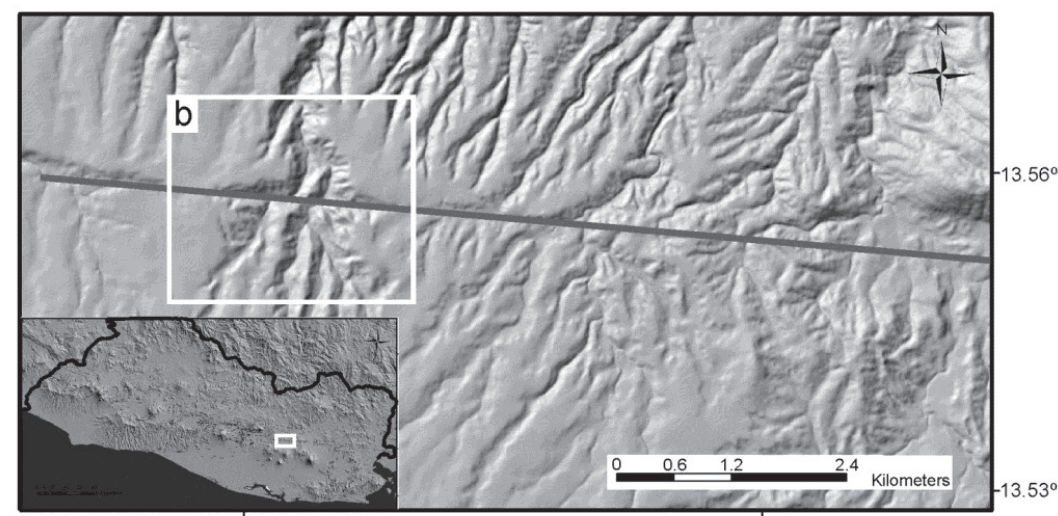

$-88.45^{\circ}$

C

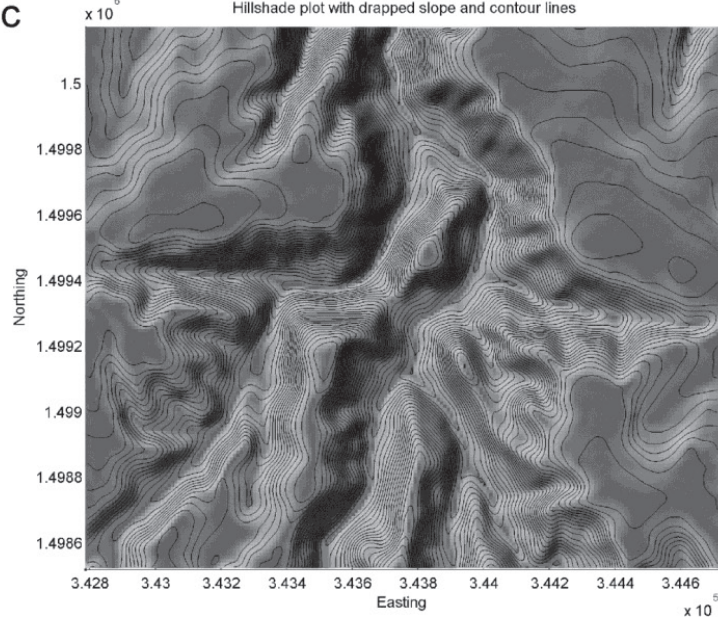

b
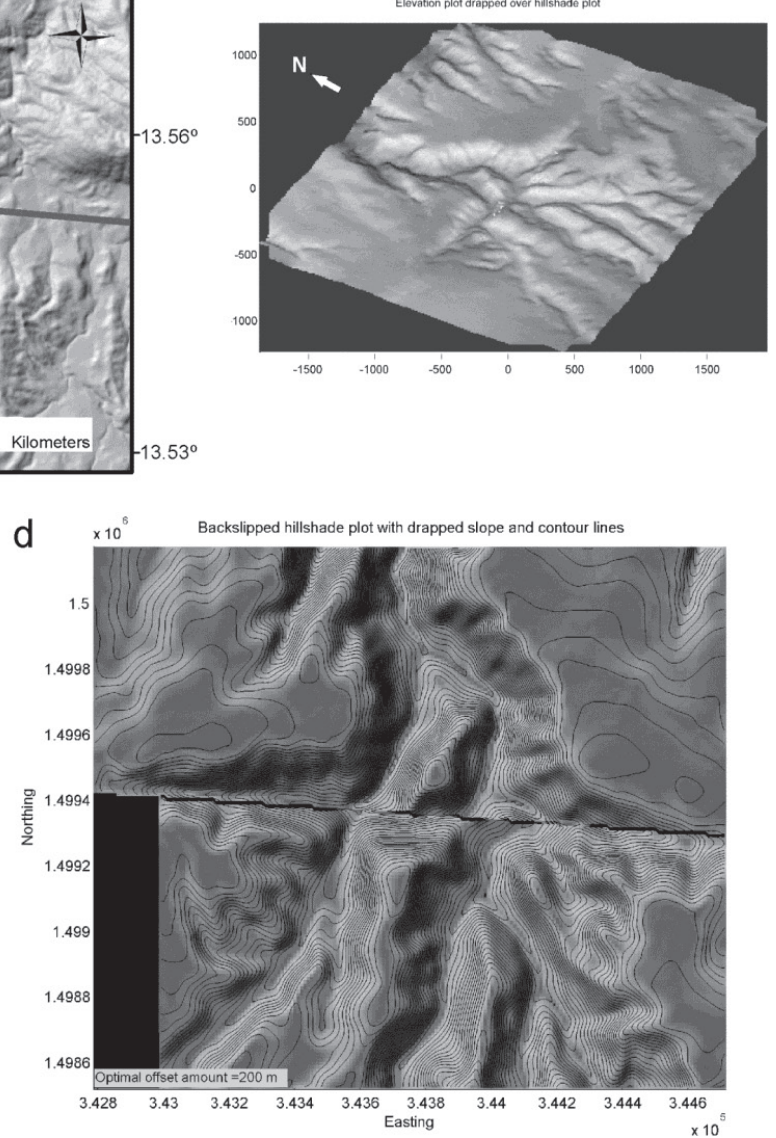

Fig. 9.- Right-lateral horizontal offset of the main rivers in El Triunfo area. The restoration of the geometry of the drainage system has been obtained with LaDiCaoz software by correlating river channels across the ESFZ. a) Location of the river offsets. b) Elevation plot of the river offsets. c) Hillshade and slope plot of the study area. d) Restored river offset. The best fit between the downstream and upstream channels is obtained for a lateral displacement of c. $200 \mathrm{~m}$. 
a

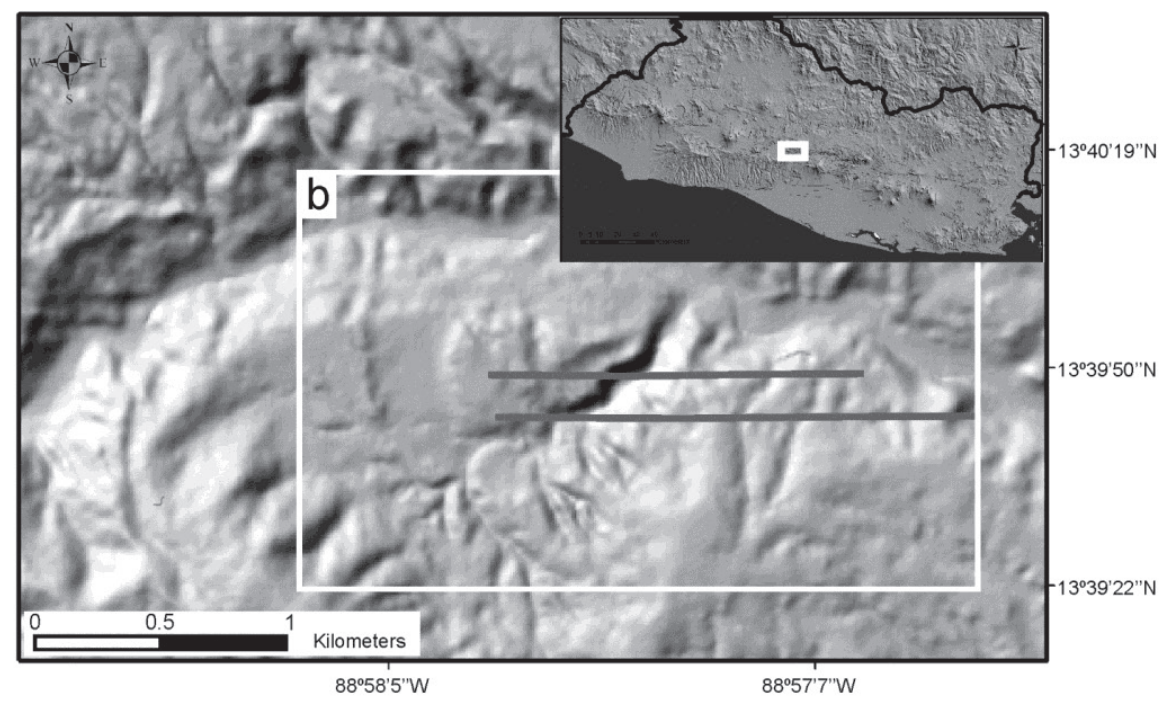

Fig. 10.- Right-lateral horizontal offset of the main rivers in Desague area. The restoration of the geometry of the drainage system has been obtained with $\mathrm{LaDiCaoz}$ software by correlating river channels across the two traces of the ESFZ. a) Location of the river offsets and fault traces. b) Restored river offset of the north trace. The best fit between the downstream and upstream channels is obtained for a lateral displacement of c. 80 m. c) Restored river offset of the south trace. The best fit between the downstream and upstream channels is obtained for a lateral displacement of c. 120 m. d) Elevation plot over the hillshade with the restored river offset. e) Oblique surface hillshade with the restored river offsets.
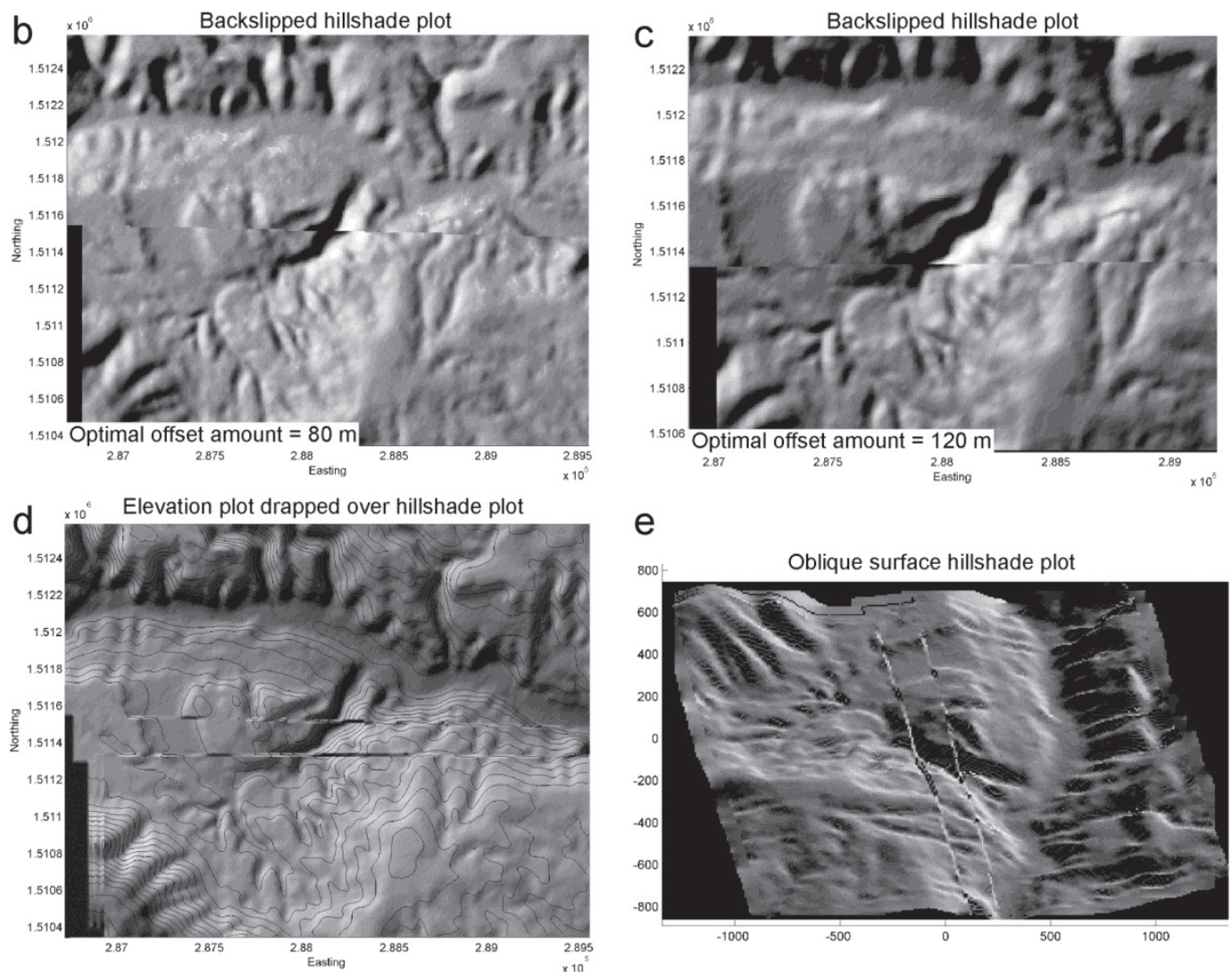

rate of c. $5.3 \pm 0.5 \mathrm{~mm} / \mathrm{yr}$. To the east, on Berlin segment, another caldera (Fig.11b) presents an offset of around $3 \pm 0.5$ $\mathrm{km}$ within the Cuscatlan Formation, dated at one million year from geological mapping (Bosse et al., 1978). This yields a slip rate of $3 \pm 0.5 \mathrm{~mm} / \mathrm{yr}$. This second structure does not seem to be affected by significant changes in elevation, so we consider that the vertical component of the fault was low for the Berlin segment.

\subsection{GPS analysis}

In order to understand how deformation is accommodated within the ESFZ, we analyzed the Alvarado et al. (2011) GPS velocities (Fig.12). We have made a velocities projection along three profiles perpendicular to the ESFZ, assuming that the normal component to the profile represents the strikeslip velocity of the fault zone. The fault-parallel velocities along the profile A (Fig.13) shows a deformation of $\sim 12 \mathrm{~mm} /$ $\mathrm{yr}$ accommodated over $60 \mathrm{~km}$, mostly absorbed between Guaycume (GF) and El Limón (ELF) faults. These faults are probably the northern and southern boundaries respectively of the central graben of El Salvador. Along the central profile B (Fig.13) we can observe a deformation rate of $\sim 11.5$ $\mathrm{mm} / \mathrm{yr}$, most of it, $\sim 10 \mathrm{~mm} / \mathrm{yr}$, could be accumulated around San Vicente (SVF) and Apastepeque (AF) faults. However, we are not confidence enough about the information from 

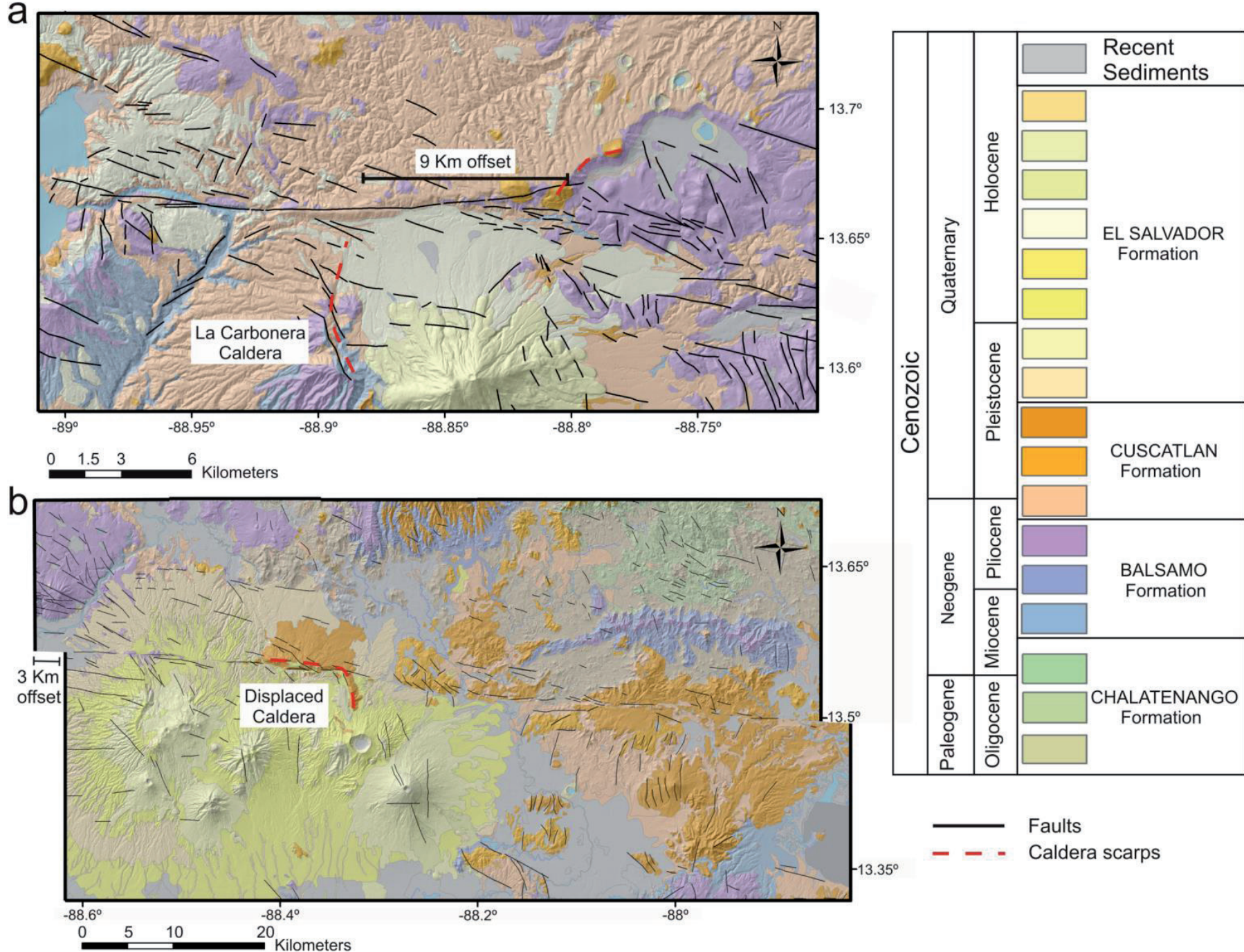

Faults

- - - Caldera scarps

Fig. 11.- a) Geology of San Vicente segment over DTM, showing a possibly right-lateral displacement of the Carbonera Caldera of c. 9 km. b) DTM with the geology of Berlin segment showing the restoration of the geometry of an old caldera by sliding back the two sides displaced by the fault. The best fit between the north and south blocks is obtained for a lateral displacement of c. $3 \mathrm{~km}$.

the BT10 station and we consider that more data would be needed along this profile to achieve better conclusions. The profile C (Fig.13) shows a wide deformation area with a rate of $\sim 6 \mathrm{~mm} / \mathrm{yr}$, mostly accommodated in the southern part of the profile. It is possible that the deformation of ESFZ is distributed southeastward in this area by normal faults. The deformation rate in this profile is lower than that obtained in the previous profiles, which is consistent with the transmission of the deformation to the south of the Intipuca range.

In addition, we calculated the velocity gradient tensor (Malvern, 1969) from the horizontal velocity field from Alvarado et al. (2011) GPS velocities, and we have made a triangular network using each site velocity, where the triangles are optimally close to equilateral with a Delaunay triangulation (Watson, 1982). Then the velocity gradient is used to obtain an average strain and rotation rates within the network. The strain rates calculated from the horizontal velocity field are shown in terms of their principal axes in figure 14. Figure 15 shows the antisymmetric part of the velocity gradient tensor, the average rate of rotation around a verti$\mathrm{cal}$ axis. Both figures are very consistent with a transtensive regime for ESFZ. The higher extensional component coincides with the Lempa pull-apart basin, and, as is shown in figure 15 , the highest rotations take place in the same area.

\subsection{Slip rate and GPS velocities}

The long term (geological offsets), medium term (river offsets) and short term (paleoseismic analysis) slip rates estimated for the central part of the ESFZ (San Vicente and Berlin segments) give an average value of $4.475 \pm 0.55 \mathrm{~mm} /$ yr (Table 1). If we compare this result with the recently GPS velocities data (Alvarado et al., 2011) on this part of the fault (Fig.12), we can observe a slip rate deficit of around $5 \mathrm{~mm} / \mathrm{yr}$. This deficit could be explained by alternative reasons: 1) the deformation is highly distributed in several main fault planes and several secondary faults within a broad band (or fault zone) and our values only account for part of the deformation 


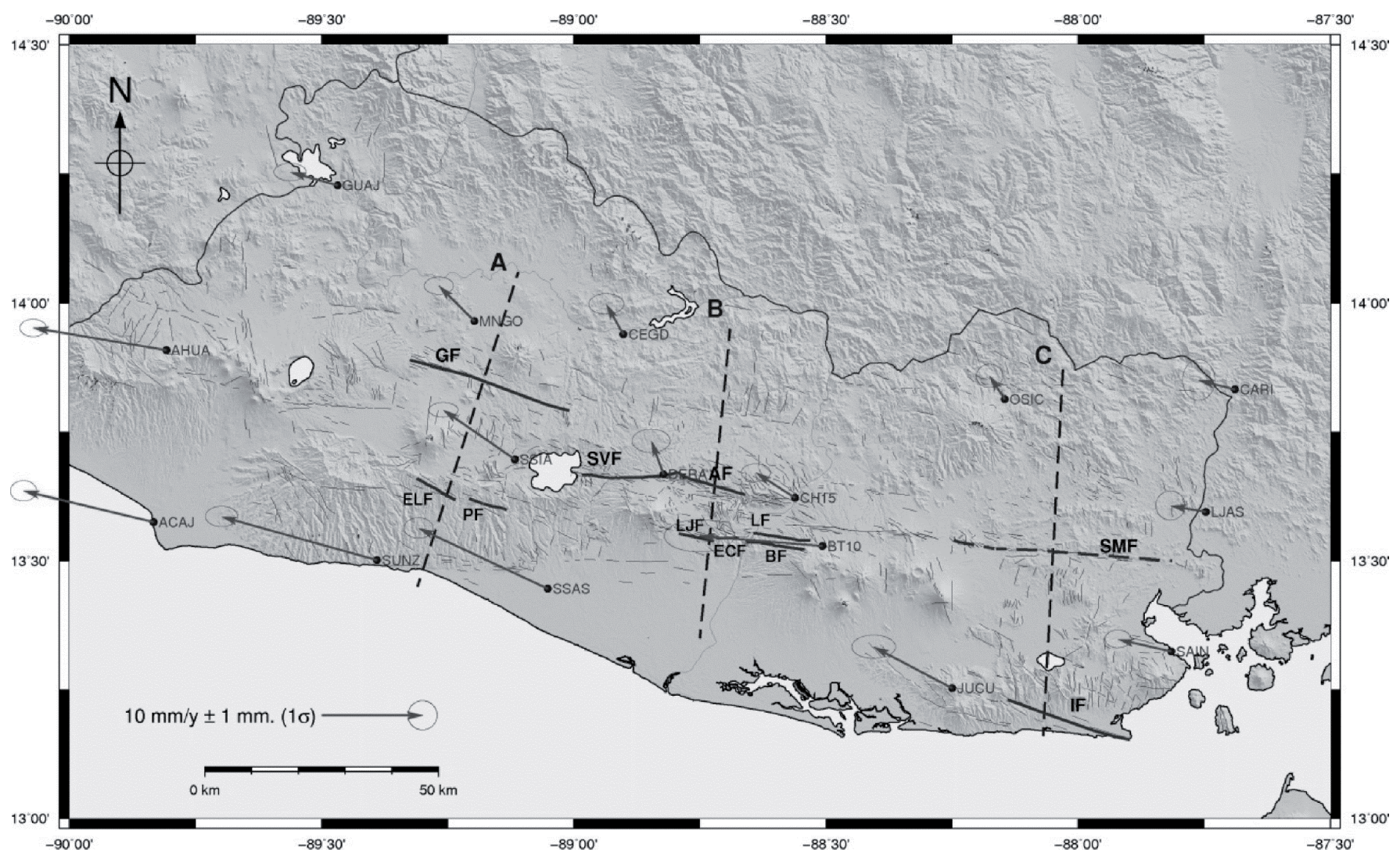

Fig. 12.- GPS station velocities (arrows) in the study area relative to a stationary Caribbean plate from Alvarado et al. (2011) data. Ellipses show two-dimensional (2-D) $1 \sigma$ velocity uncertainties. Black lines outline main active faults, grey lines are low displacement active faults. Dashed lines show the figure 13 A, B and C profiles location. Topography is from Shuttle Radar Topography Mission (Farr and Kobrick, 2000). Dots are the GPS stations. Fault abbreviations: GF-Guaycume Fault; ELF-El Limón Fault; PF-Panchimalco Fault; SVF-San Vicente Fault; AF-Apastepeque Fault; LJF-La Joya Fault; LF-Lempa Fault; ECF-El Caracol Fault; BF-Berlín Fault; SMF-San Miguel Fault; IF-

2) our geological values are not complete due to extensive resetting of the landscape during the recent volcanic eruptions which produced thick ignimbrites and air fall deposits (Cuscatlan Formation, Tierra Blanca 3, Berlin Ignimbrite and Tierra Blanca Joven among others) and; 3) our geological values are not complete because tectonic landform can be reset by high erosion rates due the strong soil weathering within the tropical region and/or the erodible nature of the volcanic deposits; Ongoing measurements on a denser GPS network (ZFESNET) around the fault zone (Staller et al., 2008) will provide more precise velocity data that may help explain the slip rate deficit.

\section{Discussion}

We propose that the ESFZ is a poorly developed strike-slip fault zone within a transtensional regime over a previous extensional structure. A recent study (Canora et al., 2012) suggests that the strike-slip ESFZ could have developed along a pre-existing graben structure, described by Carr (1976), on the presence of opposite facing fault scarps to the north and south of the active volcanoes. The fact that the faults affecting older materials are not long and not linked to each other sug- gests that the fault zone is rather young. Furthermore, the faults surface expression in Quaternary sediments is not related to the volcanic origin of these materials but with the evolution of the fault zone. Our model is based on the results of detailed analysis of fractures and faults attitude within the ESFZ, and comparisons between the faults patterns existing in El Salvador and those obtained by analogue and kinematic models.

Scaled analogue models have been successfully applied to the analysis of the deformation patterns that are developed in strike-slip regimes (Schreurs, 1994; McClay and Dooley, 1995; Schreurs and Colletta, 1998; Schreurs, 2003; Holohan et al., 2008). The comparison of the results of this work with those from experimental works can shed some light on the level of structural development of the ESFZ. El Salvador is widely covered by recent volcanic soft deposits from volcanic eruptions. The thickness of these deposits is very large along the volcanic axis, mainly in the central and western part of the fault, where rhyolitic volcanism is dominant. For example, the last eruption of Ilopango Caldera, TBJ, launched a total volume of $18 \mathrm{~km}^{3}$ of dense rock equivalent (Hart, 1981, 1983). The shallow structure of the ESFZ is developed on these young deposits, which overlay more rigid formations (Balsamo formation; Rose et al., 1999). 
Fig. 13.- Topography and Caribbean GPS velocities projected along three profiles perpendicular to the ESFZ. Normal motion is shown in black and parallel motion to the profile in white. Main active fault traces are indicated by vertical dashed line. The horizontal dashed line represents the variation between stations. See figure 12 for profile locations. Fault abbreviations: GF-Guaycume Fault; ELF-El Limón Fault; AF-Apastepeque Fault; LJF-La Joya Fault; SMF-San Miguel Fault; IF-Intipuca Fault.

\section{Profile A}

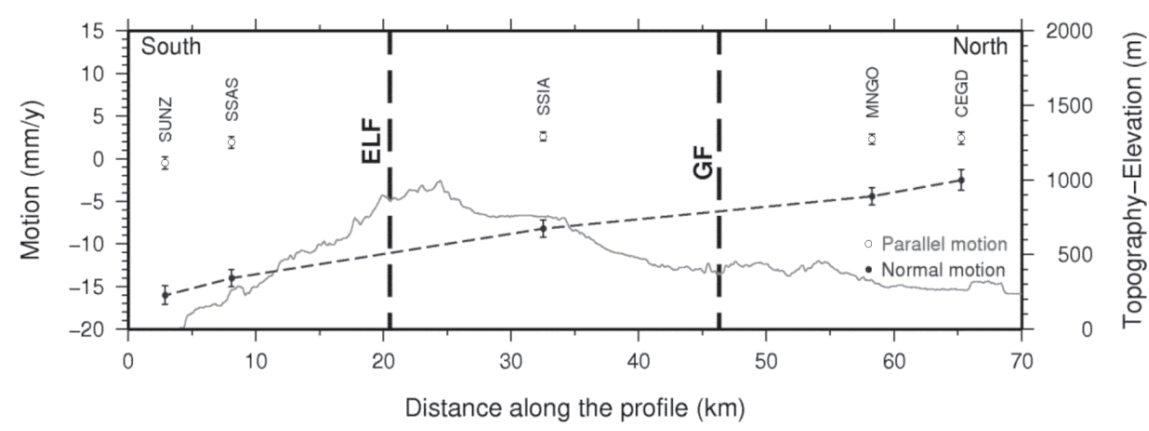

Profile B

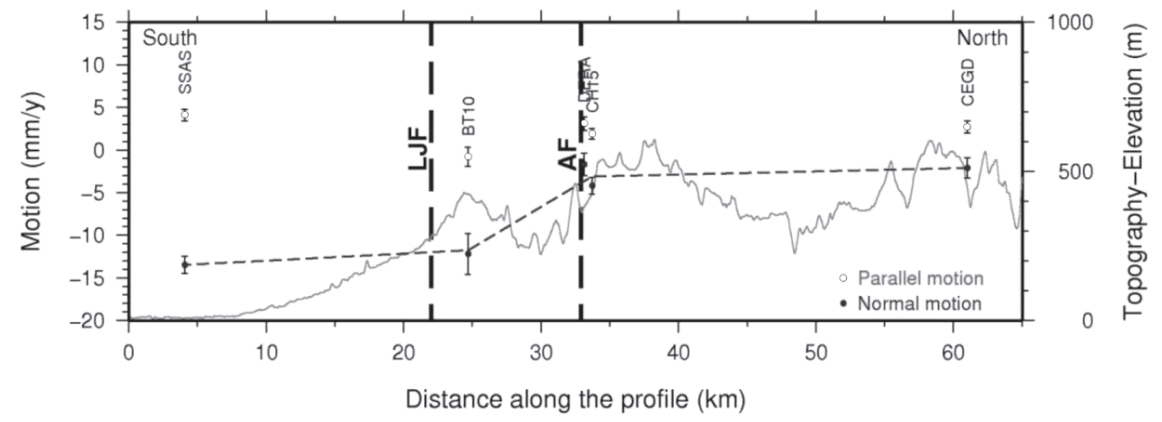

Profile C

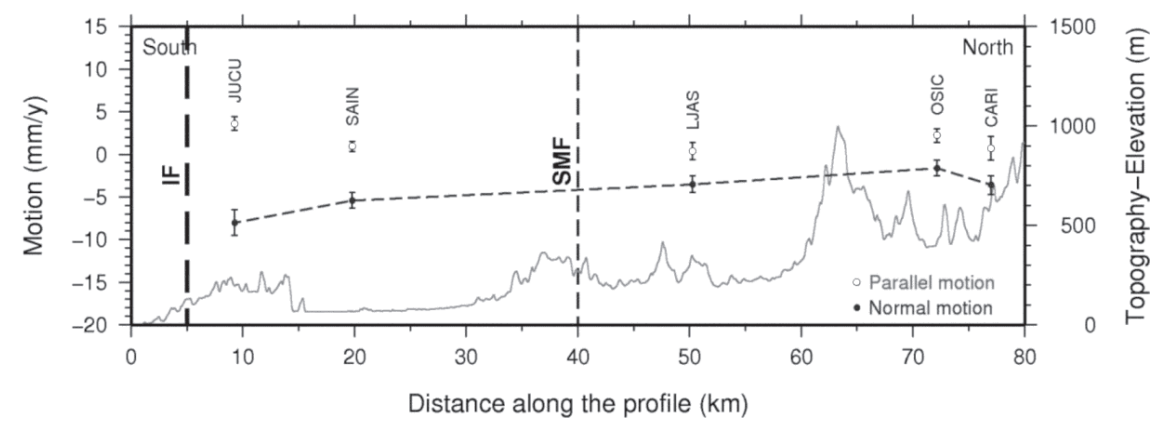

The absence of well-developed principal displacement zones (Y planes) (Riedel, 1929 and Schreurs and Colleta, 1998) indicates that the ESFZ (at least in shallow levels) is still in the first stages of its evolution. In pure strike-slip fault analogue models (Fig.16b), the first formed features are the synthetic Riedel shears (R) (Logan et al., 1979), which are oriented between $23^{\circ}$ and $35^{\circ}$ to the applied shear direction (Schreurs, 1994). In the ESFZ, the N120 E striking faults represent the R shears. In the analogue models, almost simultaneously to R shear features, antithetic Riedel shears (R') appear, striking at $70-78^{\circ}$ to the applied shear direction. In the ESFZ, R' shears are represented by N-S striking faults. With progressive shearing, early faults remain active while new faults form. Two types of secondary faulting develop, usually between major overlapping R shears: (1) arrays of evenly spaced, sinistral strike-slip faults striking at about $60^{\circ}$ (R'L) and dextral strike-slip faults striking at lower angles (RL) that previously formed R shears. With increasing strain, the angle between the strike of newly developed cross faults and the shear direction diminishes. Cross faults usually terminate at earlier formed master faults (Y planes, Fig.16c) and are poorly represented in the ESFZ, indicating that the fault has not reached this level of maturity.

The ESFZ presents a fault pattern typical of strike-slip faults developed under a transtensional regime. If we observe the general geometry of the ESFZ (Fig.16a), the principal displacement zone highlighted with thick black traces has a concave to the north east shape, having an angle between SHmax and the fault trend about $30^{\circ}$, which suggests a larger extensional component in the western part of the ESFZ and the development of WNW-ESE and NW-SE normal faults and tectonic depressions where the active volcanism is located.

In transtensional distributed strike-slip shear analogue models (Schreurs and Colletta, 1998), the strike of shallow faults is slightly different from that of early strike-slip faults at depth (Fig.16c). Antithetic, sinestral strike-slip faults develop in between the major dextral strike-slip fault zones. The strike of the newly developed antithetic faults in shallow levels rotates with increasing deformation: the orientation of the main compressive stress axis rotates counter clockwise toward the strike of the early formed synthetic strike-slip faults (Schreurs, 1994). With continuing deformation, normal 


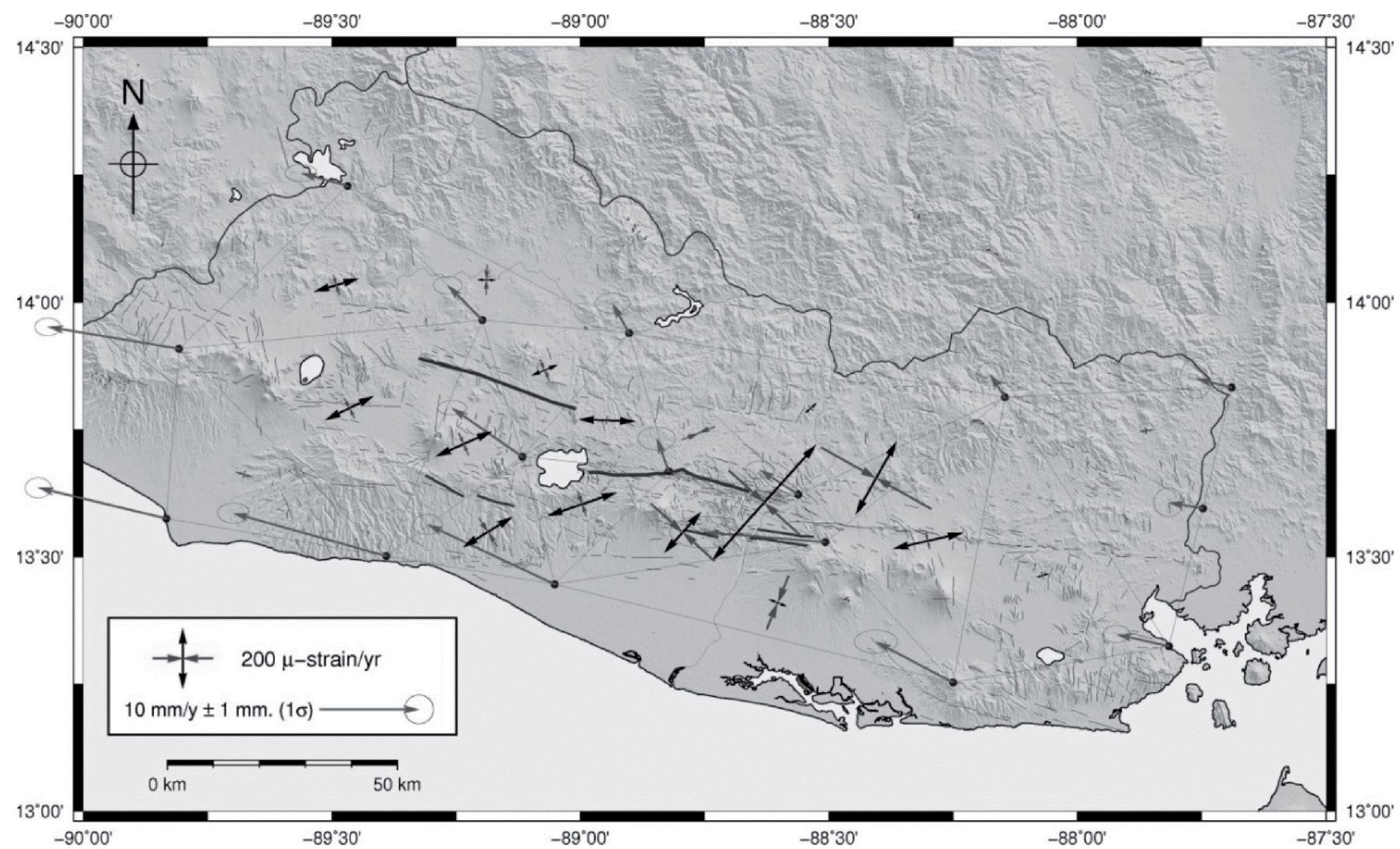

Fig. 14.- Principal axes of the horizontal strain rate tensors in the area around ESFZ, calculated for the Caribbean velocity field of Alvarado et al. (2011) shown in figure 12. In each Delaunay triangle, the inward pointing arrows represent compression; outward pointing arrows represent extension.

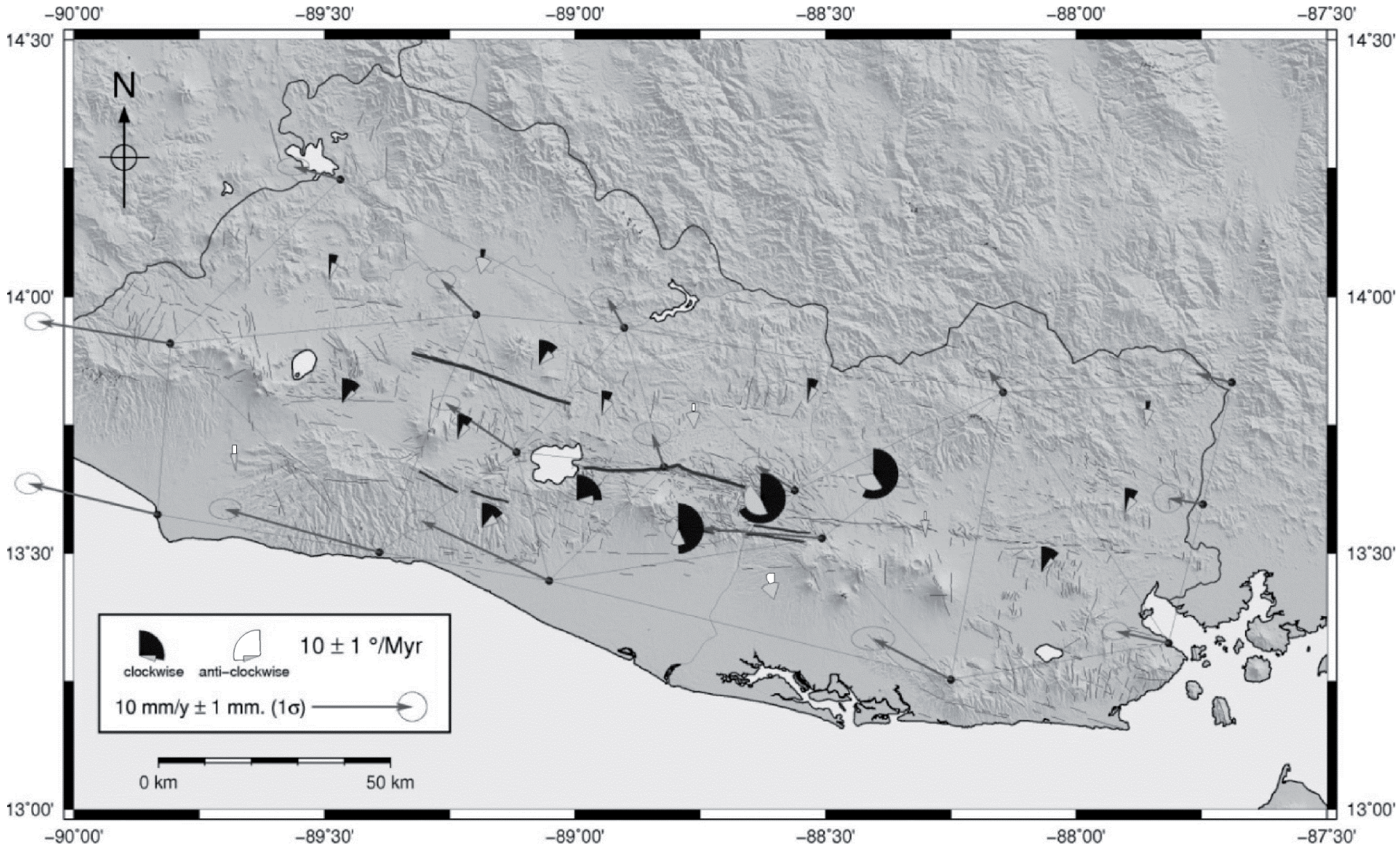

Fig. 15.- Average rotation rates inferred from the Caribbean velocity field of Alvarado et al. (2011) shown in figure 12. Black color wedges depict clockwise block rotations and white color wedges depict anticlockwise rotations. 
Fig. 16.- a) Preferred kinematic model for EL Salvador. Large displacement faults are shown in black lines. The coloured grey area represents the depressed zone. The names associated with the faults (R, R', Y, $\mathrm{T}$ and P) refer to the Riedel (1929) shear terminology. b) Results from a pure strike-slip sandbox model with the formation of different types of faults (Schreurs, 1994). c) Results from a transtensional strikeslip sandbox model (Schreurs and Colleta, 1998).
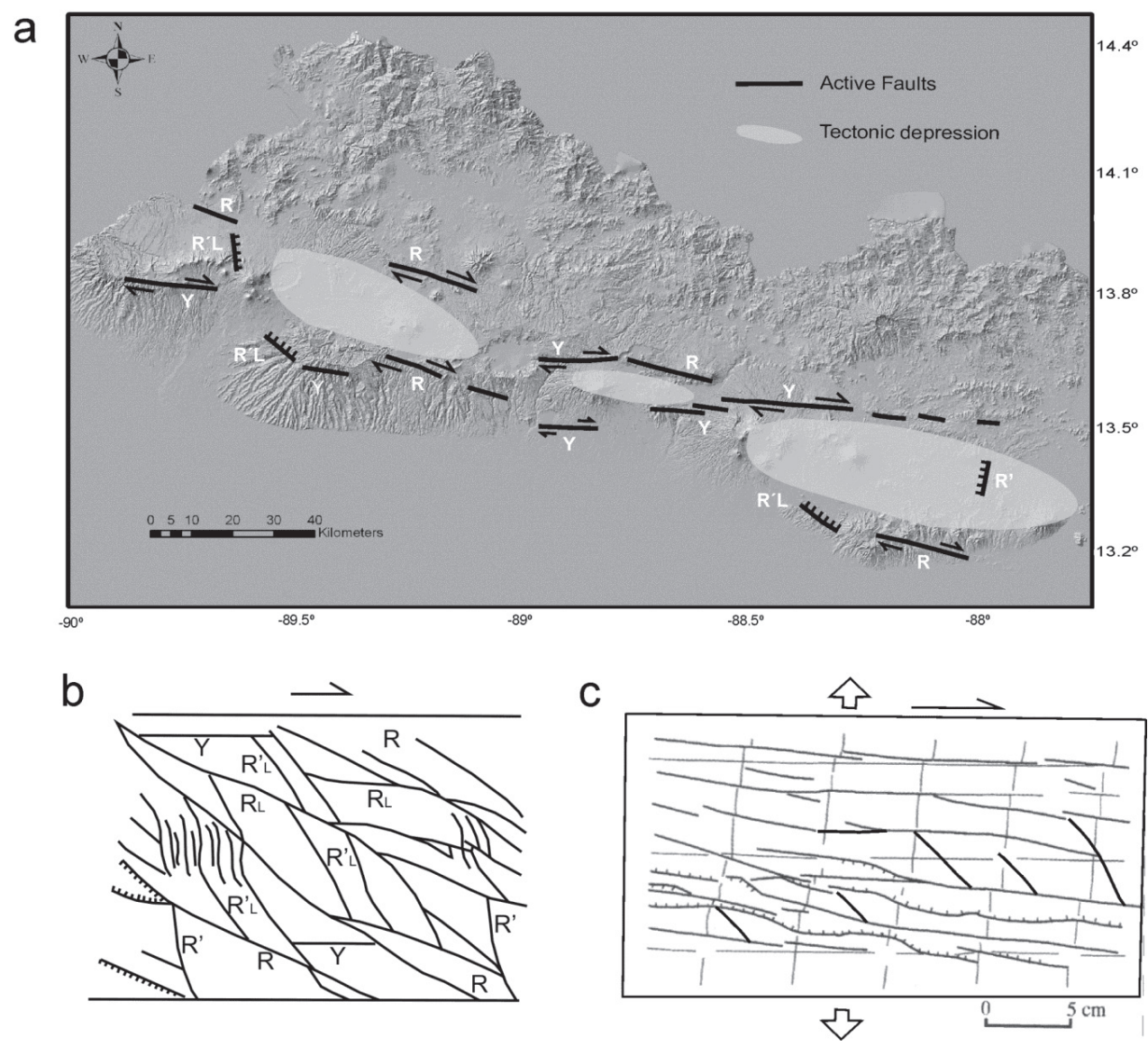

faults, develop between and parallel to earlier, form major synthetic strike-slip faults. Normal faults dip at angles between $60^{\circ}$ and $70^{\circ}$, and have no or only limited horizontal offset. Their development implies local changes in the orientation of the maximum principal stress axis from horizontal (strike-slip faulting) to vertical (normal faulting).

Especially interesting are the cross cutting relationships among the different fault sets around the Lempa basin. In figure 3a we can observe the Riedel faults intersecting previous extensional faults around the Lempa basin, generated by the transtensional strain regime. This indicates that the fault is evolving and that with increasing deformation the WNWESE Riedel faults are increasingly developed. According to the aforementioned analogous models, as the deformation progresses, the Riedel faults will connect with the E-W direction Y planes, resulting in a more continuous fault zone. If so, this features indicates an incipient phase of development in the ESFZ.

However, some of the fault characteristics displayed by the ESFZ are difficult to explain as a consequence of transtensional deformation. For example, the large scarp (80 metres high) bounding the northern border of the Lempa basin and the scarp of the San Vicente segment, north of the San Vicente volcano, are too high to be created just as a component of the transtensional strike-slip movement. Formation of large vertical scarps due to normal faulting would require very large Quaternary slip, not coherent with neither measured GPS velocities nor slip rates obtained from paleoseismic analy- sis (Correa-Mora et al., 2009; Alvarado et al., 2011; Canora et al., 2012). A plausible explanation for these large vertical scarps and the presence of the longitudinal depression named "Median trough of El Salvador" (Williams and Meyer-Abich, 1955; Carr, 1976), is that the tectonic regime prior to the current transtension was purely extensional and a graben structure was present in the area. We propose that this region of El Salvador underwent a similar geodynamic evolution to that of the Nicaragua graben. Weinberg (1992) proposed that the present-day deformation affecting the Nicaraguan depression is controlled by a right-lateral transtensional regime localized along the volcanic front and it is superimposed to the previous rift. During the Pliocene, Nicaragua area suffered a northeast-southwest extension which produced the opening of the Nicaraguan depression (Weinberg, 1992). According to Schellart (2005), decreased plate velocities or convergence rates would induce slab rollback, with subduction retreat in a seaward direction, that in turn produces backarc or intra-arc extension in the overriding plate, and generated trench parallel normal faults trending $\mathrm{N} 130^{\circ} \mathrm{E}$. Current deformation occurs in multiple active fault families trending both parallel and transverse to the trend of the depression. El Salvador could have underwent a similar regional extensional phase, in that period, but at lower extensional rates producing smaller and discontinuous graben structures along the volcanic arc (Burkart and Self, 1985). Some of those old features have being captured by newly formed parallel strike-slip faults during the development of ESFZ. 
Fig. 17.- Evolution model for the ESFZ from pure trench orthogonal extension, on the left-upper part of the figure, to transtension movement on the right-upper part of the figure and the present stage on the logger part. Abbreviations: N, normal faults; Y, Y planes; R, Riedel planes; WS, west segment; SVS, San Vicente segment; LS, Lempa segment; BS, Berlin segment; SMS, San Miguel segment; SA, Santa Ana volcano; SS, San Salvador volcano; IL, Ilopango caldera; SV, San Vicente volcano; BE, Berlin volcano; SM, San Miguel volcano.
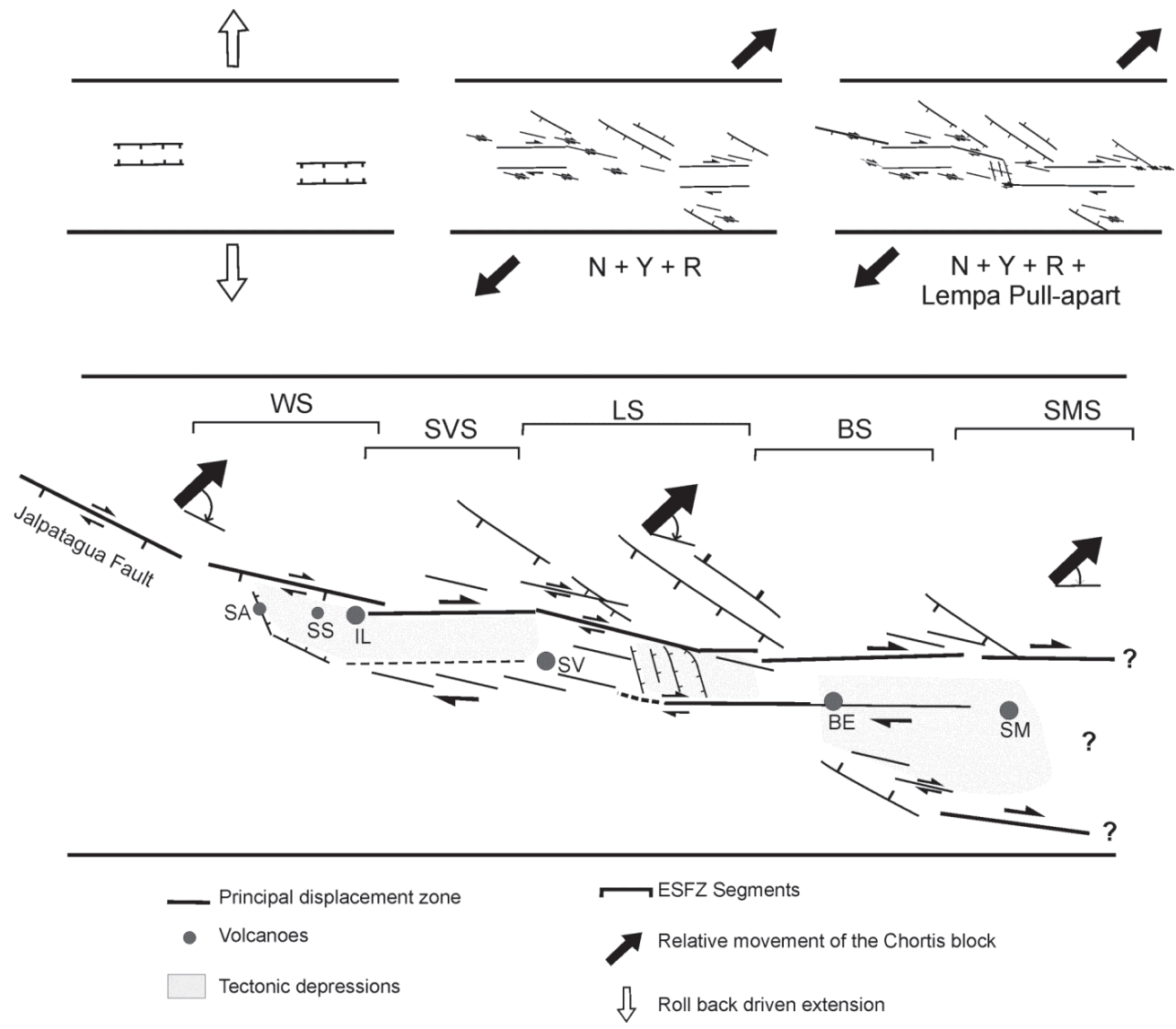

Funk et al. (2009) proposed that ESFZ is a major rightlateral strike-slip fault that accommodates large-scale, northwestward displacement of the Central America forearc sliver. In that study, extension becomes localized at fault stepovers. Deviations in the right-lateral ESFZ produce either pull-apart or restraining bends with large volcanoes preferentially localizing within pull-apart basins. We agree that, in El Salvador, some pull-apart basins exist, but we believe that such structures are due to the transtensional regime related to the relative eastward motion of the Caribbean plate, as well as to the concave shape of the El Salvador Fault Zone.

The development model for ESFZ formation that we propose from the structural analysis and the regional tectonic evolution described above is shown at figure 17. The rightlateral transtensional regime proposed by Weinberg (1992) for the region is the accepted tectonic model for El Salvador. The absence of a significant trench-normal component of station motion in the velocities of GPS sites in Nicaragua and El Salvador imply weak or no coupling across the Cocos plate subduction interface (Cáceres et al., 2005; Guzmán-Speziale, 2001; Lyon-Caen et al., 2006). The dextral strike-slip movement in El Salvador is caused by the Caribbean drift forces that produce the relative displacement of the Chortis Block to the east, owing to the required low coupling of the subducted plate (Cáceres et al., 2005; Guzmán-Speziale et al., 2005; Álvarez-Gómez et al., 2008; Correa-Mora et al., 2009; Franco et al., 2012). The complexity of the ESFZ structure and the kinematics variations along strike is associated with the incipient character of the shallow fault zone structure and the lateral variation of the angle between the principal displacement zone and the Caribbean drift forces (transtension). In our model (Fig. 17) we have a first phase of extension with the formation of normal faults with large vertical displacements. Subsequently transtensive stage begin and dextral strike-slip faults start to develop, using previously formed normal fault planes, and also Riedel and normal faults appeared. As deformation progresses some pull-apart basins bounded by strike-slip faults and normal faults new arise. Finally, in what would be the current situation, strike-slip faults are increasingly developing forming a more continuous fault zone.

Based on the proposed model, the structure at the south eastern area of El Salvador would fit with an extension zone. This feature cannot absorb all the strike-slip motion that exists in the area because of the forearc sliver relative movement toward the northwest (as we can see from the GPS data, figure 12) and this result in a depressed area with the formation of penetrative north-south normal faults.

\section{Conclusions}

The ESFZ is a poorly developed strike-slip fault zone formed within a transtensional regime and imposed over a previous extensional structure. At surface, the fault appears as a complex network of traces related to major rupture segments with various geometries, kinematics and geomorphic 
expressions. In the west segment, the ESFZ shows a grabenlike structure. Active volcanisms occupy the lower altitude regions on this structure, which are bounded by NW-SE strike-slip faults with minor normal component of slip.

Right-lateral steps of the main fault trace in the central area of the ESFZ (San Vicente - Berlín area) produce a pull-apart structure, the Lempa basin. We propose that this structure is enclosed in a larger releasing bend that can comprise other small basins.

The strike-slip deformation in the eastern part of the ESFZ (San Miguel segment) seems to be transferred to the south. The presence of N-S penetrative normal faults and WNWESE oblique (normal faults with strike-slip component) faults indicates an extensional or transtensional regime in this area that could be part of the ESFZ. A specific study is required to determine the relationship between ESFZ and the faults structure and kinematic in this area.

From natural fault exposures and paleoseismic trenches excavated along the San Vicente segment we documented that the strike-slip deformation is distributed in several planes that converge at depth probably in one main fault. The angular relationships between these faults and the geometry of the fault zone are typical of a strike-slip fault developed under a transtensional regime.

The concave shape of the ESFZ may enhance a larger extensional component in the western part of the fault. The large vertical scarps documented along the ESFZ suggest the presence of a pre-existing graben structure because they would require Quaternary slip rates not coherent with neither measured GPS velocities, nor slip rates obtained from paleoseismic analysis. We envision that these structures were inherited from a previous regional roll back related to an extensional stage. The traditionally named "Median trough of El Salvador" is the relict of a Pliocene extensional structure that was then used by the ESFZ to grow up along it.

The estimated slip rate for the main fault planes of ESFZ is $4.475 \pm 0.55 \mathrm{~mm} / \mathrm{yr}$ as a minimum, and implies a deficit in the velocity of the fault compared to the available GPS velocities data. The missing deformation can be associated with faults outside of the study area. Further analyses are required to locate those faults and determined the earthquake hazard.

Understanding the distribution of deformation and location and activity rate of faults is essential to implement appropriate land use planning and seismic resistant design, and efficient emergency management in a country with a rapid population expansion and with steep topography and major landslide susceptibility, exacerbated by deforestation.

\section{Acknowledgments}

This research Project was funded by the Spanish Ministerio de Educación y Ciencia. Ref. name: GEOTACTICA: Analysis of the active tectonics and volcano-tectonic interactions in the El Salvador using geological, geotechnical and geophysical data. Ref.: CGL2009-14405-C02-02. We are grateful to colleagues at the Observatorio Ambiental (MARN El Salvador): Douglas Hernández and Walter Hernández for their assistance in the field. The first author acknowledges financial support for this publication provided by a pre-doctoral grant of the Universidad Complutense de Madrid, Spain. Funding for Villamor's contribution was provided by the New Zealand Foundation for Research, Science and Technology and GNS Science.

\section{References}

Alvarado, D., DeMets, C., Tikoff, B., Hernández, D., Wawrzyniec, T.F., Pullinger, C., Mattioli, G., Turner, H.L., Rodriguez, M., Correa-Mora, F. (2011): Forearc motion and deformation between El Salvador and Nicaragua: GPS, seismic, structural, and paleomagnetic observations. Lithosphere 3, 1, 3-21. doi: 10.1130/L108.1

Álvarez-Gómez, J.A., Meijer, P.T., Martínez-Díaz, J.J., Capote, R. (2008): Constraints from finite element modeling on the active tectonics of northern Central America and the Middle America Trench. Tectonics 27, TC1008. doi: 10.1029/2007TC002162.

Bommer, J., Benito, B., Ciudad-Real, M., Lemoine, A., López-Menjivar, M., Madariaga, R., Mankelow, J., Mendez-Hasbun, P., Murphy, W., Nieto-Lovo, M., Rodríguez, C., Rosa, H. (2002): The Salvador earthquakes of January and February 2001: Context, characteristics and implications for seismic risk. Soil Dynamics and Earthquake Engineering 22, 389-418.

Bosse, H.R., Lorenz, W., Merino, A., Mihn, A., Rode, K., SchmidtThomé, M., Wiesemann, G., Weber, H.S. (1978): Geological map of El Salvador Republic: Hannover Germany. Bundesanstalt für Geowissenschaften und Rohstoffe, D-3 scale 1:100,000.

Bufforn, E., Lemoine, A., Udias, A., Madariaga, R. (2001): Mecanismo focal de los terremotos de El Salvador. In: Martínez-Guevara, J.M., (Ed.), Memorias 2nd Congreso Iberoamericano de Ingeniería Sísmica. Madrid, Spain, 115-118.

Burkart, B., Self, S. (1985): Extension and rotation of crustal blocks in northern Central America and effect on the volcanic arc. Geology 13, 22-26. doi: 10.1130/0091-7613

Cáceres, D., Monterroso, D., Tavakoli, B. (2005): Crustal deformation in northern Central America. Tectonophysics 404, 119-131. doi: 10.1016/j.tecto.2005.05.008

Canora, C., Martínez-Díaz, J.J., Villamor, P., Berryman, K., ÁlvarezGómez, J.A., Pullinger, C., Capote, R. (2010): Geological and seismological analysis of the Mw $6.613^{\text {th }}$ February 2001 El Salvador earthquake: Evidence for surface rupture and implications for seismic hazard. Bull. Seism. Soc. Am. 100, 6, 2873-2890. doi: 10.1785/0120090377

Canora, C., Villamor, P., Martínez-Díaz, J.J., Berryman, K., Álvarez-Gómez, J.A., Capote, R., Hernández, W. (2012): Paleoseismic of the San Vicente segment of the El Salvador Fault Zone, El Salvador, Central America. Geologica Acta 10, 103-123. doi: 10.1344/105.000001700

Carr, M.J. (1976): Underthrusting and Quaternary faulting in northern Central America. Geol. Soc. Am. Bull. 87, 825-829. doi: 10.1130/0016-7606

Correa-Mora, F., DeMets, C., Alvarado, D., Turner, H.L., Mattioli, G., Hernández, D., Pullinger, C., Rodríguez, M., Tenorio, C. (2009): GPS-derived coupling estimates for Central America subduction zone and volcanic arc faults: El Salvador, Honduras and Nicaragua. Geophysical Journal International 179, 1279-1291. doi: 10.1111/j.1365246X.2009.04371.X

Corti, G., Carminati, E., Mazzarini, F., Garcia, M.O. (2005): Active strike-slip faulting in El Salvador, Central America. Geology 33, 989992. doi: 10.1130/G21992.1 
DeMets, C. (2001): A new estimate for present-day Cocos-Caribbean plate motion: Implications for slip along the Central American volcanic arc. Geophysical Research Letters 28, 4043-4046. doi: 10.1029/2001GL013518

Dewey, J.W., White, R.A., Hernández, D.A. (2004): Seismicity and tectonic of El Salvador. In: Rose, et al., (eds.), Natural Hazards in El Salvador. Geological Society of America Special Paper 375, 363- 378.

Farr, T., Kobrick, M. (2000): Shuttle radar topographic mission produces a wealth of data, EOS, Trans. Am. Geophys. Un., 81, 583-585.

Franco, A., Lasserre, C., Lyon-Caen, H., Kostoglodov, V., Molina, E., Guzman-Speziale, M., Monterosso, D., Robles, V., Figueroa, C., Amaya, W., Barrier, E., Chiquin, L., Moran, S., Flores, O., Romero, J., Santiago, JA., Manea M., Manea, VC. (2012): Fault kinematics in northern Central America and coupling along the subduction interface of the Cocos Plate, from GPS data in Chiapas (Mexico), Guatemala and El Salvador. Geophysical Journal International 189, 3, 1223 1236. doi: 10.1111/j.1365-246X.2012.05390.x

Funk, J., Mann, P., McIntosh, K., Stephens, J. (2009): Cenozoic tectonics of the Nicaraguan depression, Nicaragua, and Median Trough, El Salvador, based on seismic-reflection profiling and remote-sensing data. Geological Society of America Bulletin 121, 1491-1521. doi: 10.1130/B26428.1

Guzmán-Speziale, M., Pennington, W. D., Matsumoto T. (1989): The triple junction of the North America, Cocos, and Caribbean plates: Seismicity and tectonics. Tectonics 8, 981-997.

Guzmán-Speziale, M., Meneses-Rocha, J.J. (2000): The North AmericaCaribbean plate boundary west of the Motagua-Polochic fault system: A fault jog in southeastern Mexico. Journal of South American Earth Science 13, 459-468.

Guzmán-Speziale, M. (2001): Active seismic deformation in the grabens of northern Central America and its relationship to the relative motion of the North America-Caribbean plate boundary. Tectonophysics 337, 39-51, doi:10.1016/S0040-1951(01)00110-X.

Guzmán-Speziale, M., Valdés-González, C., Molina, E., Martín Gómez, J. (2005): Seismic activity along the Central America volcanic arc: Is it related to subduction of the Cocos plate? Tectonophysics 400, 241254. doi: $10.1016 /$ j.tecto.2005.03.006

Hart, W.J.E. (1981): The Panchimalco tephra, El Salvador, Central America. MS thesis, Rutgers University, New Brunswick, New Jersey, 101p.

Hart, W.J.E. (1983): Classic to Postclassic tephra layers exposed in archeological sites, eastern Zapotitan valley. In: P.D. Sheets (ed.), The Zapotitán Valley of El Salvador: archeology and volcanism in Central America. Univ Texas Press.

Holohan, E.P., Van Wyk de Vries, B., Troll, V.R. (2008): Analogue models of caldera collapse in strike-slip tectonic regimes. Bulletin of Vulcanology 70, 773-796. doi: 10.1007/s00445-007-0166-x.

Logan, J.M., Friedman, M., Higgs, N., Dengo, C., Shimamoto, T. (1979): Experimental studies of simulated gouge and their application to studies of natural fault zones. USGS Open File Report, 79, 305-343.

Lyon-Caen, H., Barrier, E., Lasserre, C., Franco, A., Arzu, I., Chiquin, M., Chiquin, L.M., Duquesnoy, T., Flores, O., Galicia, O., Luna, J., Molina, E., Porras, O., Requena, J., Robles, V., Romero, J., Wolf, R. (2006): Kinematics of the North American-Caribbean-Cocos plates in Central America from new GPS measurements across the PolochicMotagua fault system. Geophysical Research Letters 33, L19309, DOI: 10.1029/2006GL027694.

Malvern, L.E. (1969): Introduction to the mechanics of a continuous medium, Prentice Hall, Englewood Cliffs, N.J., 713 pp.

Martínez-Díaz, J.J., Álvarez-Gómez, J.A., Benito, B., Hernández D. (2004): Triggering of destructive earthquakes in El Salvador. Geology 32, 65-68. doi: 10.1130/G20089.1

McClay, K.R., Dooley, T. (1995): Analogue models of pull-apart basins.
Geology 23, 711-714.

Plafker, G. (1976): Tectonic aspects of the Guatemala earthquake of 4 February 1976. Science 193, 1201-1208.

Price, N.J., Cosgrove, J.W. (1990): Analysis of geological structures, Cambridge Press, 502 pp

Richard, P.D., Naylor, M.A., Koopman, A., 1995. Experimental models of strike-slip tectonics. Petroleum Geoscience 1, 71-80.

Riedel, W. (1929): Zur mechanik geologisher brucherscheinungen, Zentralblatt fur Mineralogie, Geologie und Paleontologie B, 354-368.

Rose, W.I., Conway, F.M., Pullinger, C.R., Deino, A., McIntosh, W.C. (1999): An improved age framework for late Quaternary silicic eruptions in northern Central America. Bulletin of Volcanology 61, 106120. doi: $10.1007 / \mathrm{s} 004450050266$

Rotolo, S.G., Castorina, F. (1998): Transition from mildly-tholeiitic to calc-alkaline suite: the case of Chichontepec volcanic centre, El Salvador, Central America. Journal of Volcanology and Geothermal Research 86, 117-136. doi: 10.1016/S0377-0273(98)00076-6

Schellart, W. (2005): Influence of the subducting plate velocity on the geometry of the slab and migration of the subduction hinge. Earth and Planetary Science Letters 231, 197-219. doi: 10.1029/2005GC001056

Schreurs, G. (1994): Experiments on strike-slip faulting and block rotation. Geology 22, 567-570. doi: 10.1130/0091-7613

Schreurs, G., Colleta, B. (1998): Analogue modeling of faulting in zones of continental transpression and transtension. In: R.E. Holdsworth, R.A. Strachan, J.F. Dewey (eds.), Continental Transpressional and Transtensional Tectonics. Geological Society of London, Special Publications 135, 59-79. doi: 10.1144/GSL.SP.1998.135.01.05

Schreurs, G. (2003): Fault development and interaction in distributed strike-slip shear zones: an experimental approach. In: F. Storti, R.E. Holdsworth, F. Salvini, F. (eds.), Intraplate Strike-Slip Deformation Belts. Geological Society of London, Special Publications 135, 35-52. doi: 10.1144/GSL.SP.2003.210.01.03

Staller, A., Martínez-Díaz, J.J., Benito, B., Hernández, D., Díaz, M., Pullinger, C., DeMets, C., Canora, C., Álvarez-Gómez, J.A., Béjar, M. (2008): GPS network to study the evolution of the seismic cycle of stress and strain associated to the El Salvador Fault Zone. GeoTemas 10, 1567-5172.

Tchalenko, J.S. (1968): The evolution of kink-bands and the development of compression textures in sheared clays. Tectonophysics 6, 159174. doi: 10.1016/0040-1951

Tchalenko, J.S., Ambraseys, N.N. (1970): Structural analysis of the Dasht-e Bayaz (Iran) earthquake features. Geol. Soc. Am. Bull. 81, 41-63. doi: 10.1130/0016-7606

Watson, D.F. (1982): Acord: Automatic contouring of raw data. Computers \& Geosciences 8, 97-101.

Weinberg, R. F. (1992): Neotectonic development of western Nicaragua. Tectonics 11, 1010-1017. doi: 10.1029/92TC00859

White, R.A., Harlow, D.H., Álvarez, S. (1987): The San Salvador earthquake of October 10, 1986: Seismological aspects and other recent local seismicity. Earthquake Spectra 3, 419-434.

White, R.A., Harlow, D.H. (1993): Destructive upper crustal earthquakes of Central America since 1900. Seismological Society of America Bulletin 83, 1115-1142.

Williams, H., Meyer-Abich, H. (1955): Volcanism in the Southern part of El Salvador. University of California Publications in Geologic Sciences 32, 1-64.

Wu, J.E., McClay, K., Whitehouse, P., Dooley, T. (2009): 4D analogue modelling of transtensional pull-apart basins. Marine and Petroleum Geology 26, 1608-1623. doi: 10.1016/j.marpetgeo.2008.06.007

Zielke, O., Arrowsmith, R. (2012): LaDiCaoz and LiDARimager-MATLAB GUIs for LiDAR data handling and lateral displacement measurement. Geosphere 8, 206-221. doi: 10.1130/GES00686.1 